\begin{tabular}{|l|l|}
\hline Sobre o lugar da América Latina no Brasil do século XXI, e vice-versa & Titulo \\
\hline Santos, Fabio Luis Barbosa dos - Autor/a; & Autor(es) \\
\hline Buenos Aires & Lugar \\
\hline CLACSO & Editorial/Editor \\
\hline 2016 & Fecha \\
\hline Integración regional; Pensamiento latinoamericano; Subdesarrollo; América Latina; & Colección \\
\hline Doc. de trabajo / Informes & Temas \\
\hline "http:/biblioteca.clacso.edu.ar/clacso/becas/20160311050128/FabioBarbosa.pdf" & Tipo de documento \\
\hline $\begin{array}{l}\text { Reconocimiento-No Comercial-Sin Derivadas CC BY-NC-ND } \\
\text { http://creativecommons.org/licenses/by-nc-nd/2.0/deed.es }\end{array}$ & URL \\
\hline
\end{tabular}

Segui buscando en la Red de Bibliotecas Virtuales de CLACSO http://biblioteca.clacso.edu.ar

Consejo Latinoamericano de Ciencias Sociales (CLACSO)

Conselho Latino-americano de Ciências Sociais (CLACSO)

Latin American Council of Social Sciences (CLACSO)

www.clacso.edu.ar

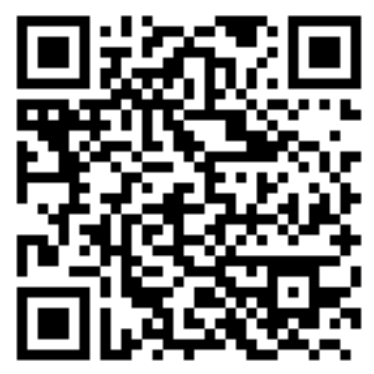




\title{
Sobre o lugar da América Latina no Brasil do século XXI, e vice-versa.
}

\author{
"Pero lo que separa y aisla a los países hispano-americanos, no es esta diversidad de \\ horario político. Es la imposibilidad de que entre naciones incompletamente formadas, \\ entre naciones apenas bosquejadas en su mayoría, se concerte y articule un sistema o \\ un conglomerado internacional. En la historia, la comuna precede a la nación. La \\ nación precede a toda sociedad de naciones" \\ José Carlos Mariategui \\ "Não adianta casar com pobre".
} Vera Thorstensen, ex-assessora da missão brasileira na OMC, sobre o Mercosul

Resumo: Tomando como ponto de partida o texto de Leslie Bethell, "O Brasil e a ideia de 'América Latina' em perspectiva histórica" (Bethell, 2009), este ensaio pretende colaborar para restituir a densidade política da noção de América Latina no século XXI, em particular para os brasileiros, associando-a à reivindicação da integração continental como uma necessidade histórica. Para realizar este objetivo, o texto realiza o seguinte movimento: inicialmente, é resgatado o contexto político e ideológico na origem do termo. A seguir, procura-se delinear os marcos gerais que balizam a evolução histórica de projetos identificados com este conceito, até analisar duas iniciativas de integração regional em curso que calçam a argumentação de Bethell, e não tem o subcontinente como referência. Na sequência, discutimos a atualidade política e ideológica da ideia de América Latina no Brasil. Sugiro que a pertinência desta noção está relacionada, por um lado, a uma apreciação da natureza dos nexos entre esta região e os Estados Unidos no mundo contemporâneo e por outro, às premissas políticas que orientam o horizonte civilizatório que se projeta para o Brasil e a região. Estabelecida a atualidade histórica e política da noção de América Latina, enuncio quais devem ser, na minha leitura, as determinações gerais de um projeto de integração continental em perspectiva emancipadora, para então analisar o alcance e os limites dos processos em curso em relação a este horizonte histórico. Minha hipótese é que há uma correspondência entre os dilemas enfrentados pelos processos políticos progressistas no continente para superar o neoliberalismo, e os impasses vivenciados pelo movimento de integração regional de orientação emancipadora.

Palavras-chave: América Latina; Integração regional; pensamento latino-americano; subdesenvolvimento; emancipação

Resúmen: Tomando como punto de partida el texto de Leslie Bethell, "O Brasil e a ideia de 'América Latina' em perspectiva histórica" (Bethell, 2009), este ensayo pretende colaborar para restituir la densidad política de la noción de América Latina en el siglo XXI, en particular para los brasileños, asociándola a la reivindicación de la integración continental como una necesidad histórica. Para realizar este objectivo, el texto realiza el siguiente movimiento: inicialmente, se rescata el contexto político e ideológico en el origen del término. En seguida, se procura delinear los marcos generales que balizan la evolución histórica de proyectos identificados con este concepto, hasta analisar dos iniciativas de integración regional en curso que sostienen el argumento de Bethell, y no tienen al subcontinente como referencia. En la secuencia, se discute la actualidad política e ideológica de la ideia de América Latina en Brasil. Sugiro que la pertinencia de esta noción está relacionada, por un lado, a una apreciación de la naturaleza de los nexos entre esta región e Estados Unidos en el mundo contemporáneo y por otro, a las premisas políticas que orientan el horizonte civilizatório que se proyecta para el Brasil y la región. Establecida la actualidad histórica y política de la noción de América Latina, 
enuncio cuales deben ser, en mi lectura, las determinaciones generales de un proyecto de integración continental en perspectiva emancipadora, para entonces analisar el alcance y os límites de los processos en curso, en relación a este horizonte histórico. Mi hipótesis es que hay uma correspondencia entre los dilemas enfrentados por los processos políticos progressistas en el continente para superar el neoliberalismo, y los impasses experimentados por el movimiento de integración regional de orientación emancipadora.

Abstract: Taking as a point of departure Leslie Bethell's article "“O Brasil e a ideia de 'América Latina' em perspectiva histórica", this essay intends to colaborate to reassert the political density of the notion of Latin America in the XXI century, particularly among Brazilians, associating it to the pursuit of continental integration as a historical necessity. With that aim, the text undertakes the following movement: at first, the political and ideological context at the origins of this notion are restated. Then, we sketch the general guidelines that bound the historical evolution of projects identified with this concept, until we analyse two ongoing regional integration iniciatives that sustain Bethell's argument, and that have not the subcontinent as a reference. Next, we discuss the political and ideological relevance of the idea of Latin America in Brasil at the present time. I suggest that the pertinence of this notion is referred, on one hand, to an aknowledgment of the particularity of the relation between this region and the United States in the contemporary world, and in the other hand, to the political premises that guide the projected historical horizon to Brazil and the region. Once established the historical and political relevance of the notion of Latin America, I state what should be, in my view, the main determinations to a continental integration project under an emancipatory perspective, to then analyse the potential and the limits of the ongoing process, regarding this historical horizon. My hypothesis is that there is a relation between the dilemmas faced by the political progressive processes in the continent to overcome neoliberalism and the deadlocks experienced by the regional integration movement on an emancipatory perspective.

\section{Introducão}

Questionar o estatuto político e cultural da América Latina não é uma novidade, como denunciam as linhas iniciais do ensaio de autoria do poeta e crítico literário cubano Fernández Retamar escrito em 1971, “Caliban”(Fernández Retamar, 2004). Ao longo do século XX, alguns dos intelectuais mais criativos do continente se debruçaram sobre esta problemática, que teve como principal expoente nos campos da filosofia e da história das ideias o mexicano Leopoldo Zea (Zea, 1976; 1986; 1993). A novidade é ver um historiador inglês decretar a inutilidade do conceito, o que talvez gerasse pouca repercussão não fosse o fato de que este acadêmico organizou uma obra de referência sobre a área: a História da América Latina editada pela Universidade de Cambridge, 
traduzida para o castelhano e o português, e indicada como referência bibliográfica em cursos superiores sobre o tema ao redor do mundo (Bethell, 1990-1996; Bethell, 19972009). A pedra angular do raciocínio apresentado pelo professor para desmontar o conceito é defender a impertinência de considerar o Brasil como parte da região no século XXI, o que instiga brasileiros que pensem o contrário a se manifestarem.

Em seu texto "O Brasil e a ideia de 'América Latina' em perspectiva histórica", publicado no país em 2009, o historiador inglês Leslie Bethell inicialmente reconstitui a construção da ideia de América Latina no século XIX. A seguir, o autor mostra que os hispano-americanos não integravam o Brasil em suas discussões, assim como os brasileiros tampouco se enxergavam como partícipes de projeções de unidade continental. Bethell argumenta que é somente após a Segunda Guerra que se gesta no país a percepção de uma identidade latino-americana. Em um raciocínio análogo ao que John Phelan construiu sobre a afirmação da América Latina como uma denominação continental, visão que comentarei logo mais, o historiador inglês sugere que o motor desta mudança de percepção não seria endógeno, mas radica em alterações na formulação da política externa dos Estados Unidos, que passam a encarar o continente desta maneira. Bethell encerra seu texto indicando que, pela primeira vez em sua história, a política externa brasileira tem como foco a América do Sul (mas não a América Latina), interpretada como um caminho para afirmar-se como uma potência regional. O texto é concluindo com a seguinte sentença: "É chegada a hora de o mundo parar de considerar o Brasil como parte daquilo que, na segunda metade do século XX, foi chamado de América Latina, um conceito que seguramente perdeu a utilidade que talvez tenha tido alguma vez" (Bethell, 2009: 289).

O presente artigo toma como ponto de partida as proposições de Bethell, somadas a diálogos entabulados em visita a UNILA (Universidade Federal da Integração Latino-Americana) em Foz do Iguaçu - universidade que, como o próprio nome anuncia, tem como referência a integração continental - para uma reflexão orientada a restituir a densidade política da noção de América Latina no século XXI, em particular para os brasileiros. Seu fio condutor é o nexo estabelecido entre as duas proposições conclusivas do artigo do historiador inglês: a impertinência em considerar o Brasil como parte da América Latina na atualidade, e como decorrência, a inutilidade do próprio conceito. Contrapondo-se a este raciocínio, procuro restituir as premissas históricas que conferem sentido à noção de América Latina como expressão de um desígnio de unidade continental, e como desdobramento, reafirmar os fundamentos políticos de um horizonte civilizatório para o Brasil referido a América Latina. Reestabelecido o estatuto político desta noção, analiso as iniciativas integracionistas em curso, indicando o ressurgimento de um horizonte de integração continental como necessidade histórica, entendido como fundamento de um projeto orientado a superar a articulação entre dependência e superexploração do trabalho que caracteriza a formação latino-americana, no contexto da globalização e do neoliberalismo.

\section{Atualidade da América Latina}

1.

Os dois estudos seminais em torno à gênese do termo América Latina foram publicados no ano de 1965, respectivamente pelo historiador estadunidense John Phelan 
e pelo filósofo uruguaio Arturo Ardao (Phelan, 1986 (1965); Ardao, 1965; 1980). Phelan argumenta que a noção de "América Latina" como uma entidade geopolítica foi cunhada e difundida nos marcos da ideologia panlatina forjada durante o império de Napoleão III na França. O historiador estadunidense sugere que o nexo ideológico entre a "Europa Latina"- expressão de curso corrente no Velho Mundo naquela conjuntura - e a "América Latina", seria principalmente obra de um funcionário do império enviado ao Novo Mundo em decênios anteriores, Michel Chevalier. Nesta perspectiva, o termo indicaria uma área de potencial influência francesa na América, legitimando a invasão ao México iniciada em 1861 no contexto da Guerra da Secessão nos Estados Unidos, mesmo ano em que Chevalier publicou o artigo que Phelan considera como a referência original à expressão. A decorrência de maior impacto da hipótese do historiador estadunidense é uma leitura segundo a qual o termo "América Latina" teria sido forjado e difundido nos marcos da política expansionista francesa para o continente.

Quase simultaneamente ao trabalho de Phelan, Arturo Ardao apresentava resultados de uma pesquisa apontando em sentido diverso. O filósofo uruguaio mapeou múltiplas referências a uma "América Latina" em diversos políticos e publicistas da América hispânica em meados do século XIX, até identificar nos escritos do granadino José María Torres Caicedo nos anos 1850, e mais especificamente em um poema intitulado "Las dos Américas", uma mudança significativa: o termo "latino" tornara-se um substantivo, e não mais um adjetivo de América. Desde então, a paternidade da expressão tem sido objeto de polêmica. O historiador chileno Miguel Rojas Mix defende a primazia de seu compatriota Francisco Bilbao, que teria veiculado o termo em uma conferência em Paris em 1856, cidade em que também vivia Torres Caicedo. Rojas sugere que o intelectual granadino apropriou-se do termo empregado por Bilbao, quem posteriormente o abandonaria por motivos políticos, como resposta crítica à invasão francesa ao México (Rojas Mix, 1986).

Mais recentemente, a historiadora Aims McGuiness identificou a expressão em um texto intitulado "La cuestión americana y su importancia", publicado no mesmo ano de 1856 pelo representante panamenho no Senado colombiano, Justo Arosemena. Reivindicado posteriormente como uma espécie de patrono do nacionalismo panamenho, Arosemena defendeu na ocasião um projeto de união hispano-americana em termos similares aos avançados por Torres Caicedo, ao mesmo tempo em que lutou pela autonomia desta província colombiana (McGuiness, 2008; Arosemena, 1982).

O contexto que produziu esta circulação simultânea da expressão é iluminado pelo livro da historiadora estadunidense, Path to Empire. Estudando as relações entre a corrida para o oeste nos Estados Unidos e a questão social e racial na região do istmo do Panamá, a historiadora sugere nexos entre os conflitos decorrentes da expansão estadunidense e a difusão da expressão "América Latina". Em 1848, mesmo ano em que foi assinado o tratado Guadalupe-Hidalgo consumando a expansão territorial dos Estados Unidos a expensas do México vencido na guerra, anunciou-se a descoberta de ouro na Califórnia. Este episódio desencadeou migrações massivas de americanos do leste para o oeste do país, forçados a atravessar o continente por um de seus pontos mais estreitos: seja o istmo de Tehuantepec no México, a rota nicaraguense aproveitando-se do lago no interior do país, ou mais comumente, através do Panamá, que integrava a Nova Granada (futura Colômbia) naquele momento. Este afluxo em massa de estadunidenses à região causou diversos conflitos analisados por Guiness, culminando na primeira de muitas intervenções militares estadunidenses na história panamenha, em 1856.

É neste mesmo ano que, após prestar serviços à facção vencedora na guerra civil entre Leon e Granada, ascendeu à presidência da Nicarágua o famoso filibusteiro William Walker. Múltiplas motivações se entrelaçaram na empreitada deste filho do 
Tenessee, incluindo a disputa entre empresários ianques pela exploração da rota interoceânica através do Lago Nicarágua, e o projeto sulista de adicionar um voto escravista à federação, como pretendeu a fracassada expedição de Narciso Lopez a Cuba em 1850. De fato em seu breve governo, reconhecido pelos Estados Unidos, Walker aboliu as leis anti-escravistas. Deposto por uma coligação militar liderada pelo presidente da Costa Rica, o filibusteiro prosseguiu em suas atividades até ser executado por autoridades hondurenhas em 1860.

Antes de serem episódios isolados, estes eventos evidenciam o movimento de expansão estadunidense, embalado pela ideologia do destino manifesto, em uma conjuntura em que os interesses do país também se expandiam em direção à Ásia (Williams, 1962). É este o substrato político da ocorrência simultânea da expressão em Torres Caicedo, Bilbao e Arosemena - quem diga-se de passagem, cita a conquista do Texas, o filibusteiro William Walker e a expedição do Comodoro Perry ao Japão em sua defesa do "interés latinoamericano". Assim, a despeito da polêmica em torno do pioneirismo no emprego do termo, a senda aberta por Ardao mostra que, ainda que a matriz ideológica subjacente à expressão "América Latina" seja tributária da cultura europeia em geral e francesa em particular, foi como uma reação política nativa à projeção estadunidense, particularmente na América Central, que o termo ganhou a densidade histórica que o consagrou.

2.

Afastando-se da polêmica em torno à paternidade do termo, a historiadora argentina Monica Quijada critica a visão de Phelan adicionando um argumento político ao debate, ao perguntar-se porque adotariam os latinoamericanos um termo identificado com uma agressão unanimemente condenada na região. Aceitando a gestação endógena da expressão, Quijada enfoca, portanto, um problema diverso: porque a expressão América Latina foi adotada nos anos seguintes, em detrimento de concorrentes como América Espanhola ou Gran Colombia (Quijada, 1998)?

Segundo esta historiadora, a explicação decorre da confluência entre dois fatores: o ressurgimento de tendências que advogavam a unidade entre os países da América espanhola, em resposta ao expansionismo estadunidense, e a "racialização" das categorias explicativas, parte de um fenômeno geral no ocidente no século XIX. Assim, tanto Bilbao como Torres Caicedo (bem como Arosemena, que não é citado em seu texto), referem-se à oposição entre a América Latina e a América anglosaxônica em termos raciais: "la raza latinoamericana", descreve o chileno no seu "Evangelho Americano", enquanto o poema do segundo diz:

\section{La raza de la América latina \\ al frente tiene la sajona raza}

Neste sentido, embora gestada na América hispânica, a dicotomia entre América Latina e América Anglosaxônica está referida a um vocabulário e a uma visão de mundo característicos da Europa do século XIX, em que era corrente a oposição entre a Europa Latina e a Anglosaxônica, ou germânica, como lembra Quijada: "De hecho, al promediar el siglo XIX era tan normal hablar de las "razas" en general, de la división del género humano en "razas superiores" e "inferiores" e incluso de las rivalidades entre la "raza latina" y la "germana" o "anglosajona", como lo es hoy referirse a "culturas", a "naciones", o a las rivalidades entre Estados" (Quijada, 1998: 24).

Quais as vantagens subjetivas, do ponto de vista dos hispanoamericanos, em adotar a denominação "América Latina"? Segundo a historiadora espanhola, a filiação 
latina conferia projeção universal aos seus dilemas, inscritos na oposição entre latinos e anglosaxões, o que poderia motivar simpatia europeia a sua causa, mas, sobretudo, pode ser interpretado como uma maneira de afirmar o estatuto civilizatório daqueles que Benedict Anderson chamou como os Estados Criollos (Anderson, 2003). O intelectual chileno Walter Mignollo, que também se debruçou sobre o problema, acrescenta uma perspectiva de classe a este argumento quando aponta que a reivindicação latina não contradizia a reprodução dos privilégios sociais, assentada na discriminação de negros e indígenas no continente (Mignollo, 2005).

A identidade latino-americana se afirmaria nos decênios seguintes à luz dos esforços do secretário de Estado norte-americano James Blaine para concretizar uma união panamericana, em nome da qual convocou uma conferência em Washington nos anos 1880. No entanto, seria a intervenção dos Estados Unidos na guerra de independência de Cuba em 1898 - que se converteu então em uma "Guerra Hispanoamericana", o marco referente desta consciência hispano-americana, como mostra entre outros, o crítico literário espanhol Teodosio Fernández (Fernández, 2000). A indignação frente à agressividade dos Estados Unidos aproximaria homens de letra hispanoamericanos das raízes espanholas do continente, a despeito da simpatia generalizada com a causa cubana prevalente na época. Assim, no próprio ano de 1898, Ruben Dario mobilizou a figura de Caliban em defesa do campo hispânico, e na virada do século, o uruguaio José Enrique Rodó celebrizará no continente a dicotomia com Ariel em seu ensaio. Entre outras expressões desta consciência identitária nos anos seguintes é possível mencionar, em polos opostos do sub-continente, a utopia da "Nação Latinoamericana" avançada pelo argentino Manuel Ugarte, e as especulações em torno a uma "raça cósmica" do ministro revolucionário mexicano José Vasconcelos - indicando a longevidade da noção de raça na América Latina, ainda que em uma direção humanista, sugerida pela consigna que batizou a UNAM (Universidad Nacional Autonoma de México): "por mi raza hablará el espíritu".

Retomando o argumento de Monica Quijada, observa-se que no processo de afirmação da identidade latino-americana no final do século XIX e princípios do século $\mathrm{XX}$, confluem uma reação ao expansionismo estadunidense com o que a historiadora espanhola denomina como uma "racialização" das categorias explicativas. Assim, a "América Latina" afirma-se em oposição à "América Anglo-saxônica" e por aproximação ao legado latino da cultura europeia. Depois dos eventos na América Central que motivaram o termo na sua origem, Quijada identifica na Primeira Conferência Panamericana convocada por James Blaine e na Guerra da Independência Cubana entre 1895-98, dois marcos sucessivos neste processo identitário.

Houve um personagem que participou destes dois eventos e cujo ideário, na minha leitura, endossa a interpretação de Quijada por um caminho complementar. O cubano José Martí (1853-1898) participou da Conferência Panamericana em 1889 como delegado pelo Uruguai e teve atuação decisiva juntamente com o delegado argentino, Roque Saenz Peña, para frustrar os desígnios estadunidenses. Saenz Peña, que depois seria presidente da Argentina, cunhou o lema "América para a humanidade" em oposição à doutrina Monroe, enquanto Martí pronunciou um de seus discursos mais famosos, "Madre América", em um evento cultural em que estavam presentes os delegados da Conferência.

Martí também foi o mentor intelectual e principal articulador do Partido Revolucionario Cubano, fundado poucos anos depois (1892), responsável por desencadear a Guerra da Independência em 1895. Exegetas do pensamento martiano, como Fernandez Retamar, localizam no final dos anos 1880 a maturação do ideário do militante cubano, que se condensaria no projeto de Nuestra América. Dois eventos são 
considerados determinantes para esta evolução: os protestos operários em Chicago no ano de 1886 (que estão na origem do $1^{\circ}$ de maio como dia do Trabalhador) e a referida Conferência Panamericana. Deve-se lembrar que Martí vivia nos Estados Unidos, depois de circular por diversos países latino-americanos (como México, Guatemala e Venezuela), já que estava banido de Cuba desde a sua prisão aos dezessete anos - pena que seu pai, um militar espanhol em serviço na ilha, conseguiu comutar pelo exílio.

Consciente da vulnerabilidade da posição cubana, premida entre o colonialismo espanhol e o expansionismo estadunidense, Martí inscreverá a guerra da independência nas Antilhas em uma problemática mais ampla: o destino da América Latina. Para realizar este movimento, o cubano realiza o seguinte percurso ideológico: em primeiro lugar, busca um denominador comum entre os países americanos ao sul do Rio Bravo, que localizará na história: Martí identifica uma origem comum, que por sua vez, projeta um potencial civilizatório conjunto, percepção sintetizada em uma linha de sua alocução Madre América: "Del arado nació la América del Norte, y la Española, del perro de presa" (Martí, 2000: 420-27, tomo 2).

Em segundo lugar, Martí valoriza a especificidade da cultura latino-americana, na qual identifica um potencial civilizatório único e original, ao mesmo tempo em que salienta o estatuto particular da cultura europeia. Como premissas desta reivindicação do americano, Martí integra o indígena e o negro ao seu projeto de formação nacional e continental, em contraste notável, por exemplo, com Justo Arosemena, cuja confederação americana discriminava negros e aborígenes. A democratização radical do seu projeto político encontra correspondência em um movimento no plano das ideias, em que o pensador cubano rechaça a noção de raça como categoria social válida: " $E l$ hombre no tiene ningún derecho especial porque pertenezca a una raza o otra: dígase hombre, y ya se dicen todos los derechos" (Martí, 2000: 205, tomo 2).

Este humanismo radical que embasa a política martiana o leva a desmascarar o substrato ideológico da dicotomia civilização e barbárie, nas antípodas do pensamento de Sarmiento: (...) el pretexto de que la civilización, que es el nombre vulgar con que corre el estado actual del hombre europeo, tiene derecho natural de apoderarse de la tierra ajena perteneciente a la barbarie, que es le nombre que los que desean la tierra ajena dan al estado actual de todo hombre que no es de Europa o de la América europea" (Martí, 2000: 450, tomo 1). É pertinente recordar que Martí conheceu, quando esteve no Haiti, a Antenor Firmin, autor da obra "De l'égalité des races humaines", uma resposta contundente proveniente da república negra das Antilhas ao ensaio de Gobineau sobre a desigualdade das raças humanas, de extraordinária repercussão na Europa (Firmin, 2005).

Em suma, ao projetar a luta cubana sobre o destino latino-americano, Martí buscou na história elementos de uma identidade comum cuja especificidade procura valorizar, o que o leva a rechaçar a racialização das categorias: é este humanismo radical que substancia a aliança social que sustenta a política do PRC, sintetizada na consigna: "con todos y para el bien de todos".

Por outro lado, enfrentando simultaneamente o colonialismo espanhol e o expansionismo estadunidense, Martí afasta-se de uma identificação do destino continental com a cultura latina e projeta um horizonte civilizatório próprio, alicerçado na autoctonia. Nas suas palavras, "La universalidad europeia ha de ceder a la universalidad americana". Daí a valorização dos povos aborígenes, traduzida na afirmação de que a nossa Grécia é preferível à Grécia que não é nossa, por nos ser mais necessária, assim como o vinho de plátano: "Injértese en nuestras repúblicas el mundo; pero el tronco ha de ser el de nuestras repúblicas", sentencia Martí (Martí, 2000: 483, tomo 
O ideário humanista martiano é sintetizado na noção de "hombre natural", que supõe uma natureza humana transcendente para o homem americano, em contraste com o materialismo que domina a sociedade europeia e estadunidense. Martí propõe para o continente uma sociabilidade alternativa, alicerçada em uma racionalidade amorosa de inspiração cristã em oposição ao "ódio de classes" prevalente nas sociedades industriais.

Premido entre o colonialismo espanhol e o expansionismo estadunidense, Martí projeta para o continente um horizonte civilizatório alternativo, que não está referido à Europa latina nem aos Estados Unidos. Face a este dilema, é levado a buscar uma denominação que reflete de maneira lapidar os paradoxos envolvidos: nuestra América, termo empregado anteriormente por diversos americanos, mas cujo sentido político original é geralmente atribuído a Francisco de Miranda (Bohórquez Morán, 2003). Ao adotar este termo, Martí assume a denominação europeia para a região, apropriada pelos Estados Unidos ("América"), indicando ao mesmo tempo, que o subcontinente está destinado a não ser latino nem americano - no sentido inferido pela Doutrina Monroe. Afirma que seremos América afinal - como vislumbraram os europeus e projetaram os estadunidenses - mas do nosso jeito.

Assim, convergem no ideário de nuestra América um projeto geopolítico defensivo face ao expansionismo estadunidense e uma utopia humanista própria e original, de alcance universal. É neste duplo sentido que o pensador cubano identificou o desenlace da guerra nas Antilhas com o "equilíbrio del mundo": "La guerra de independencia de Cuba, nudo del haz de islas donde se ha de cruzar, en plazo de pocos años, el comercio de los continentes, es suceso de gran alcance humano, y servicio oportuno que el heroísmo juicioso de las Antillas presta a la firmeza y trato justo de las naciones americanas, y al equilibrio aún vacilante del mundo" (Martí, 2000: 517, tomo $3)$.

Retomando o diálogo entre a hipótese de Quijada e a análise de Martí verificamos que, impossibilitado de identificar o destino latino-americano com a Europa latina em uma circunstância em que a Espanha era o inimigo imediato, o pensador cubano descarta a racialização das categorias ao mesmo tempo em que refere à autoctonia o horizonte civilizatório de sua utopia de unidade continental face ao expansionismo estadunidense. Antes de ser uma operação ideológica, este movimento corresponde a uma radicalização política de sentido democrático do projeto martiano, que permite situá-lo entre os esforços pioneiros para subordinar o desenvolvimento capitalista aos desígnios da sociedade nacional no contexto de difusão das relações de produção capitalistas no continente.

Nesta perspectiva, o desenlace da Guerra da Independência cubana, em que a intervenção militar estadunidense no ocaso do conflito frustra a emancipação nacional, encerra um paradoxo. Por um lado, conforme já observado, a imediata derrota espanhola no confronto com os Estados Unidos no Caribe e na Ásia provocou uma onda de hostilidade à potência americana, que se desdobrou em uma reivindicação da latinidade, evidenciada na repercussão do ideário arielista esboçado por Rodó. Por outro lado, na crítica arielista à "nordomania", ressoa a racialização das categorias referida por Quijada. A radicalidade democrática do projeto martiano derrotado, em que índios e negros eram protagonistas, é dissolvida em uma ideologia compatível com a reprodução dos privilégios sociais que caracterizavam as repúblicas criollas coevas.

Para nomear o problema em vocabulário político contemporâneo, a reação prevalente aos acontecimentos de 1898 na América Latina evidenciou a dimensão nacional do anti-imperialismo a expensas do seu conteúdo de classe, prefigurando um 
dilema recorrente na política democrática do continente ao longo do século $\mathrm{XX}^{1}$. É este descolamento entre soberania e igualdade que o intelectual cubano Fernández Retamar endereçou quando, no contexto da revolução cubana, reivindicou o papel de Caliban em lugar de Ariel para a América Latina, invertendo a leitura de Rodó.

3.

Até este ponto, indicamos que a noção de América Latina se afirma em resposta à expansão estadunidense, em um contexto em que a racialização das categorias informa um projeto político de unidade do subcontinente. Na sequência, ao recuperar o ideário martiano, observamos que a superação das categorias raciais corresponde a uma radicalização da dimensão democrática da integração nacional, que se articula à reivindicação de uma originalidade histórica como ponto de apoio de um projeto de unidade continental, vislumbrado simultaneamente como uma estratégia geopolítica defensiva face aos Estados Unidos, e um horizonte civilizatório próprio de estatura universal.

Nesta altura, é possível localizar com precisão as premissas políticas que fundamentam a vitalidade do conceito de América Latina no século XXI: a pertinência de uma política de integração continental para contrabalançar as pressões do capital internacional em geral e dos Estados Unidos em particular, nos marcos de uma estratégia para assumir o controle sobre o tempo e o ritmo da mudança social, objetivando afirmar sociedades relativamente equitativas e autorreferidas. Ou para enunciar em uma linha, sua pertinência está referida a uma apreciação da atualidade de um projeto de unidade continental no contexto do imperialismo.

\section{Historicidade da unidade continental}

Tomando como referência as considerações acima sobre o conteúdo político do conceito de América Latina, abordarei a seguir uma segunda proposição de Bethell, sugerindo a impertinência de enquadrar o Brasil como parte da América Latina no século XXI. Desenvolverei meu argumento em dois movimentos articulados, assentados em premissas enunciadas nos parágrafos anteriores. Por um lado, recupero sucintamente a historicidade dos projetos de unidade continental, lembrando que seu conteúdo evolui em consonância com o próprio movimento da história latino-americana. Por outro lado, sugiro que a constatação de que os brasileiros raramente se enxergam ou se enxergaram como parte da América Latina, não deve servir como premissa para um argumento de viés tautológico, justificando o que se pretende explicar. Ao contrário, este distanciamento deve ser problematizado a luz da dinâmica da luta de classes no país endereçando, em última análise, a seguinte questão: a quais brasileiros interessa construir-se como parte da América Latina?

1.

Ao longo da história independente da América Latina, o desígnio de unidade continental se revela indissociável da problemática da formação nacional, entendida como a superação do legado colonial substanciada na articulação entre dependência externa e assimetria social, visando consolidar as bases materiais, sociais, espaciais,

\footnotetext{
${ }^{1}$ Para dar dois exemplos: o debate entre Mariátegui e Victor Raul Haya de la Torre, líder da APRA; e os impasses na relação entre operários e movimento indígena na história da Bolívia, em particular na revolução de 1952 - que por sua vez, remetem ao problema da aliança operário-camponesa.
} 
políticas e culturais do Estado nacional. Em outras palavras a unidade continental foi, desde Bolívar, projetada como uma estratégia defensiva, objetivando assegurar a soberania das jovens nações em um contexto internacional assimétrico e predatório. No entanto, este desígnio sempre padeceu de um paradoxo, na medida em que a almejada capacidade de guiar o próprio destino, a ser fortalecida pela união regional, se revela como requisito necessário para consumar a unidade pretendida. O intelectual e militante peruano José Carlos Mariátegui assinalou com precisão o dilema em meados dos anos 1920: "Pero lo que separa y aisla a los países hispano-americanos, no es esta diversidad de horario político. Es la imposibilidad de que entre naciones incompletamente formadas, entre naciones apenas bosquejadas en su mayoría, se concerte y articule un sistema o un conglomerado internacional. En la historia, la comuna precede a la nación. La nación precede a toda sociedad de naciones" (Mariátegui, 1990: 14).

Nesta perspectiva, o significado e o conteúdo político de um projeto de unidade latino-americana orientado à soberania evoluíram desde a independência, de maneira correspondente ao próprio dilema da formação nacional. Partindo de uma situação na qual colônia e metrópole conformam uma unidade, a trajetória dos países americanos pode ser lida como uma progressiva diferenciação em direção à nação, a qual corresponde uma percepção do continente como uma totalidade histórica. Em linhas gerais, um olhar retrospectivo sugere uma progressiva evidenciação das dimensões política, cultural, social e econômica que compõem a especificidade continental ${ }^{2}$.

Ponto de ruptura da unidade colônia-metrópole que caracterizava o antigo sistema colonial, as guerras de independência colocaram a questão da soberania como um problema político, que envolve uma dimensão cultural quando Bolívar defende instituições adequadas à realidade local. Neste contexto, a unidade continental é projetada como um meio para assegurar a independência conquistada pelas armas, e ameaçada pela reação europeia no contexto da Santa Aliança.

A necessidade de consumar a unidade nacional evidencia uma dimensão cultural da especificidade continental ao longo do século XIX, na medida em que a construção das nacionalidades enseja a afirmação de referências culturais e históricas próprias, convergentes com o processo de consolidação do Estado nacional. A dimensão continental desta problemática encontra expressão pioneira na trajetória e obra dos caraquenhos Andres Bello (1781-1865) e Simón Rodríguez (1769-1854), quem escreveu: "Donde iremos a buscar modelos?...- La América Española es original ORIGINALES han de ser sus Instituciones y su Gobierno = ORIGINALES los medios de fundar uno y otro. O Inventamos o Erramos."(Rodríguez, 1990: 88, grifos no original).

Por outro lado, nas regiões em que se evidencia a fragilidade da soberania alcançada frente ao expansionismo estadunidense a partir de meados do século XIX, ressurgem propostas de unidade continental, conforme vimos, informadas pelo vocabulário racial em voga na Europa. Novamente, o risco que se pretende prevenir é principalmente a intervenção militar, embora a ameaça primordial não seja mais a Europa, onde a Santa Aliança se esfacelou sob o espectro revolucionário de 1848, mas os Estados Unidos.

No final do século XIX, em um contexto de afirmação do capital monopolista e difusão das relações de produção capitalistas, observa-se a passagem entre uma

\footnotetext{
${ }^{2}$ A respeito da progressiva diferenciação das esferas política, cultural, social e econômica através de um processo histórico que evidenciou a especificidade da formação latino-americana, consultar: Fernández Retamar, 2005; $\quad$ Pinedo, Javier, 2010; 1976.
} 
percepção política e cultural da especificidade continental, e a apreensão dos dinamismos sociais e econômicos que conformam uma realidade própria, na qual a aspiração por soberania e integração nacional opõe-se ao movimento do imperialismo. Nesta conjuntura, afloram projetos de democratização radical das sociedades americanas em que a natureza singular desta formação histórica impõe aos militantes o desafio de discernir entre os aspectos comuns e as particularidades do desenvolvimento nacional em relação ao padrão civilizatório dos países centrais, em uma circunstância na qual fatores objetivos e subjetivos obstam esta diferenciação. Esta problemática se evidencia no contraste entre o modo como a América Latina e sua população nativa é abordada por três expoentes da política radical latino-americana na virada do século (XIX-XX), José Martí (1853-1895) em Cuba, Juan B. Justo (1865-1928) na Argentina e Ricardo Flores Magón (1874-1922) no México.

Tributário da tradição sarmentina do pensamento argentino, o socialista Juan B. Justo identifica o aborígene com a barbárie, pregando uma adesão irrestrita aos valores da civilização ocidental. No extremo oposto do sub-continente, Ricardo Flores Magón reivindica o potencial comunista das populações originárias quando os trabalhadores rurais protagonizam a Revolução Mexicana (1910-1920), enquanto a chave da política revolucionária martiana é a autoctonia, que se expressa em uma valorização do potencial civilizatório singular de nuestra América.

A despeito de numerosas especificidades dos respectivos contextos, a postura contrastante de Justo está lastreada na falta de uma percepção crítica do imperialismo, preocupação fundamental na política dos líderes cubano e mexicano. Longe de excepcional, a leitura política do socialista portenho, que pretendia engatar o vagão argentino na locomotiva civilizatória ocidental, está referida à "ilusão do progresso" que envolvia o debate político nacional, em um contexto em que o país saltara em poucas décadas da condição de deserto demográfico polvilhado de gauchos e índios, para a sexta economia mundial. A força desta ideologia é ilustrada pela baixa incidência política que teve a pregação de Manuel Ugarte, pioneiro na denúncia de um imperialismo estadunidense na Argentina, defensor da unidade latino-americana e da autodeterminação econômica do país (Ugarte, 1987; Galasso, 2001; Angel Barrios, 2007).

No polo geográfico oposto do continente, entretanto, era impossível ignorar os desdobramentos geopolíticos do processo de centralização de capitais, que se expressava no expansionismo estadunidense (LaFeber, 1969). Para Ricardo Flores Magón, assim como para todos os protagonistas da política mexicana até a Revolução (1910-1920), era necessário incluir em seu cálculo político o risco sempre presente de uma intervenção militar estadunidense. Inclusive, foi este raciocínio que levou Pancho Villa a atacar a cidade de Columbus em 1916, visando aguçar as contradições entre os governos de Carranza e Wilson (Katz, 1998). De modo análogo, para José Martí a ameaça ianque assumia a feição concreta de uma invasão militar, que afinal se consumou. Devemos lembrar, a propósito, que as tropas dos Estados Unidos operaram numerosas intervenções na América Central e no Caribe desde o século XIX e que embora as invasões fossem mais frequentes nos primeiros decênios do século XX elas não deixaram de ocorrer, como mostram as invasões a Granada (1983), Panamá (1989) e Haiti (2004).

O ponto a enfatizar é que, embora os riscos da dependência econômica não fossem inteiramente alheios a Flores Magón nem a Martí, o ângulo pelo qual encaram a unidade regional é primordialmente militar, conforme enunciado no programa do Partido Liberal Mexicano de 1905, liderado por Flores Magón: "En el establecimiento de firmes lazos de unión entre los países latinoamericanos, podrán encontrar esos países - entre ellos México - una garantía para la conservación de su integridad, haciéndose respetables por la fuerza de su unión ante otros poderes que pretendieran 
abusar de la debilidad de alguna nación latinoamericana" (Plan del Partido Liberal, em Díaz, 1974: 111).

Em suma, em um contexto em que o incipiente desenvolvimento das relações de produção capitalistas inibia a diferenciação da esfera econômica, a apreensão dos nexos entre as esferas da existência e sua relação com o capital internacional mostrava-se limitada. Neste contexto, propostas que apontam para uma unidade regional encontram maior ressonância em situações nas quais a integridade territorial e a soberania política encontram-se ameaçadas pelos Estados Unidos. Por outro lado, afloram projetos de democratização radical das sociedades americanas, em que a emergência da questão social problematiza o lugar dos não latinos nos "Estados criollos", evidenciando mais uma dimensão da especificidade continental, em um movimento que será aprofundado nos decênios seguintes em torno da questão indígena, principalmente no México e em países andinos.

2.

A possibilidade de análise política do econômico, permitindo articular os problemas nacionais e continentais ao movimento do capital internacional como uma totalidade, se consolidará com a difusão de um padrão capitalista de estratificação social, impulsionado em particular pelo processo de industrialização substitutiva de importações. É nos marcos desta evolução que a autodeterminação econômica será percebida como uma dimensão fundamental do problema da formação da nação, questão que ganhará evidência política a partir dos efeitos da crise de 1929 no continente. José Aricó constata esta inflexão para o caso argentino, observando em relação à conjuntura em que militou Juan B. Justo no começo do século XX: "En tal sentido, vale la pena recordar que salvo en las fantasmagóricas recreaciones de estas corrientes "nacionales", no existió en la Argentina anterior a los años treinta ningún grupo que opusiera un programa de desarrollo económico alternativo, y fundado en el predominio industrial, al impuesto por el bloque oligárquico-imperialista" (Aricó, 1999: 107).

Esta evolução política está lastreada em uma diferenciação da esfera econômica ${ }^{3}$, que tem como principal expressão ideológica a constituição de uma corrente de economia política latino-americana, que se consolida em torno de Raúl Prebisch a partir da fundação da CEPAL (Comissão Econômica para a América Latina) em 1947. No entanto, como mostra Eduardo Devés Valdés, este movimento articula elementos da ciência econômica contemporânea a um conjunto de motivos presentes no pensamento latino-americano ao menos desde os anos 1920, e não deve ser entendido como uma geração espontânea nem como aplicação reflexa de teorias europeias (Devés Valdés, 2000).

Nesta perspectiva, é notável que no período entreguerras o ideário de unidade continental associou-se à dimensão classista do problema da soberania, que inclui a esfera econômica, em um contexto de generalização de uma percepção antiimperialista associada ao nacionalismo. Ainda nos anos 1910, o desenlace da Primeira Guerra Mundial favoreceu uma crítica à Europa como paradigma civilizatório, ao mesmo tempo em que o triunfo bolchevique impulsionou a difusão do comunismo e do materialismo histórico na América Latina, em um momento em que o impacto da Revolução Mexicana encorajava horizontes políticos radicais. Assim, o primeiro manifesto do processo de reforma universitária que eclodiu na cidade argentina de

\footnotetext{
${ }^{3}$ Sobre o processo histórico que está na raiz do surgimento da economia política como ciência autônoma na Europa, contemporânea à Revolução Industrial, consultar: Polanyi, 2001 (1944).
} 
Córdoba em 1918 e logo se espalhou por toda a América Latina, anunciava a chegada de uma "hora americana" (La juvendud argentina, em Portantiero, 1978: 131). Entre os múltiplos desdobramentos do movimento, fundou-se uma organização com o propósito de reunir os intelectuais antiimperialistas do continente, a Unión Latinoamericana, capitaneada pelo controverso José Ingenieros.

De maior impacto político foi a constituição da APRA (Alianza Popular Revolucionaria Americana) em 1924, ainda sob a efervescência da Revolução Mexicana, sob a liderança do estudante peruano Victor Raul Haya de la Torre. Organização referente da política peruana no século XX, o partido foi originalmente projetado no México como uma organização continental. No final dos anos 1920, Haya de la Torre protagonizou com Mariátegui e o estudante cubano Julio Antonio Mella, que também aderiu ao marxismo, uma polêmica em torno da conveniência de uma estratégia de aliança antiimperialista com setores da burguesia, quando seus interlocutores comunistas questionavam, de modo pioneiro, a existência de uma burguesia nacional no continente.

No entanto, a difusão de um sentimento antiimperialista no continente, que se expressou em um apoio generalizado à resistência comandada por Sandino à ocupação estadunidense na Nicarágua no final dos anos 1920 não se traduziu, de imediato, em esforços por abordar o fenômeno a partir da economia. Embora atentasse para a importância da dimensão econômica da política ${ }^{4}$, a questão fundamental dos artigos e das polêmicas em que se envolveu Mariátegui durante sua curta vida (1895-1930) foi as classes sociais, focalizando em particular a questão indígena e o seu país, o Peru. A despeito da extravagância teórica que caracterizaram as proposições de seu compatriota Haya de la Torre, apontadas por Michael Löwy como exemplo paradigmático da tentação do "excepcionalismo indo-americano" que ameaçou o marxismo no continente no século XX (Löwy, 2003: 10), ambos autores expressam um esforço em discernir e articular o específico e o comum na formação latino-americana no contexto do capitalismo monopolista . Embora escrita em 1928, a análise do líder do APRA sobre o imperialismo, "El antimperialismo y el APRA", foi publicada somente em 1935, e sua notável difusão indica um contexto em que esta problemática se populariza no continente, como anotou Devés Valdés: "El antiimperialismo es uno de los temas recurrentes del pensamiento latinoamericano de los años 30 y puede incluso señalarse que es la forma que asume el pensamiento identitario de esos años, que se realiza como defensa de la economía continental o como nacionalismo económico" (Devés Valdés, 2000: 204).

3.

O avanço da industrialização substitutiva de importações, em um momento em que a depressão econômica do entreguerras desarticulou a divisão internacional do trabalho prevalente, gerou o contexto em que se afirmou a possibilidade de teorizar o continente como uma totalidade a partir da esfera econômica, movimento que encontrou sua expressão mais destacada na corrente de pensamento econômico que se difundiu a partir da CEPAL. Embora seja difícil precisar cronologicamente esta inflexão é possível constatar que, após a Segunda Guerra Mundial, a dimensão econômica da problemática da dependência será nuclear para os projetos políticos balizados pelo dilema da

\footnotetext{
4 "Por muy escaso crédito que se conceda a la concepción materialista de la historia, no se puede desconocer que las relaciones económicas son el principal agente de la comunicación y la articulación de los pueblos. Puede ser que el hecho económico no sea anterior ni superior al político. Pero, al menos, ambos son consustanciales y solidarios." (Mariátegui: $1990: \quad 15)$.
} 
formação nacional, assim como para as propostas de integração regional, em contraste com o lugar marginal desta questão nos esforços em teorizar a formação latinoamericana no começo do século XX.

O desenvolvimento econômico, identificado com a industrialização, passou a ser percebido como uma condição necessária embora insuficiente para afirmar a nação. Em suas formulações críticas mais penetrantes, o enfrentamento da dimensão econômica da dependência, denunciada de modo pioneiro por Raul Prebisch a partir da crítica à teoria das vantagens comparativas e ao desenvolvimento "hacia afuera" (Prebisch, 2000), foi identificado como premissa para superar a articulação entre dependência externa e o padrão de privilegiamento social característicos do subdesenvolvimento, cuja raiz histórica na América Latina remonta às estruturas da colonização: "O subdesenvolvimento tem suas raízes numa conexão precisa, surgida em certas condições históricas, entre o processo interno de exploração e o processo externo de dependência. Quanto mais intenso o influxo de novos padrões de consumo, mais concentrada terá que ser a renda. Portanto, se aumenta a dependência externa, também terá que aumentar a taxa interna de exploração" (Furtado, 1974: 94).

A partir dos anos sessenta, a evidenciação dos limites da industrialização substitutiva de importações como estratégia para enfrentar o subdesenvolvimento ensejou respostas teóricas de sentido diverso. As reflexões referidas ao pensamento cepalino enfatizaram a necessidade de, simultaneamente, expandir o mercado interno, regionalizar o processo de substituição de importações e exportar manufaturas (Nolff, 1975).

Em linhas gerais, identificavam-se constrangimentos sociais e econômicos ao aprofundamento da industrialização, que remetiam à dependência de receitas oriundas do setor exportador primário para manter o influxo de máquinas e insumos necessários à ulterior industrialização. No entanto, constatada a deterioração dos termos de troca entre bens primários e manufaturados, esta equação tenderia a manter os países da região sob recorrente endividamento externo, na medida em que procuravam no mercado financeiro internacional as divisas necessárias para manter o ritmo da expansão industrial. Esta situação de estrangulamento crônico só poderia ser estruturalmente superada mediante um ulterior adensamento do próprio processo de industrialização, resultando em um aumento progressivo da exportação de manufaturados em relação aos bens primários, ao mesmo tempo em que se reduziriam as importações ou se modificaria o seu perfil, elevado a um patamar de complexidade tecnológica superior.

Este processo exigiria, de um lado, o fortalecimento do mercado interno dos países da região, por meio da reforma agrária e de medidas que permitissem ganhos sistemáticos aos trabalhadores. Nesta perspectiva, a superação do desemprego estrutural seria uma premissa para permitir que os ganhos de produtividade industrial resultassem em uma elevação do poder de compra dos trabalhadores. A incapacidade política de resolver estes problemas apontaria para um cenário de estagnação econômica (ILPES, 1967: 387; Furtado, 1966). Por outro lado, a internalização de um setor produtor de bens de produção colocava problemas que apontam para uma necessária integração regional: "Debido a las crecientes exigencias de escala, especialización, inversiones técnicas de las industrias de sustitución de importaciones que hay que acordar en la América Latina, se piensa que sería preciso buscar la regionalización del proceso substitutivo como forma de escapar a las limitaciones impuestas por los mercados nacionales cerrados" (Nolff, 1975: 358). 
Estas limitações eram mais evidentes para os cinco países centro-americanos (Costa Rica, El Salvador, Guatemala, Honduras, Nicarágua) cuja base territorial e demográfica diminuta (em média, pouco superior a um milhão e meio de habitantes em 1950) explicitou a necessidade de integração regional, amparada pela CEPAL. Naquele contexto, a reunião destes países criaria um mercado de dimensões similares ao do Peru. Assim, desde o ano de 1951 iniciaram-se negociações neste sentido, que resultaram na assinatura de numerosos acordos bilaterais nos anos seguintes. Em 1958 firmou-se um Tratado Multilateral de Livre Comércio e Integração Econômica Centro-Americana, assim como um Convênio sobre o Regime de Indústrias Centro-Americanas de Integração. Este segundo acordo apontava para uma superação dos limites da criação de uma zona de livre-comércio, indicando o ensejo de se avançar rumo a uma nova estrutura produtiva. Em 1960, consumou-se a constituição do Mercado Centro Americano como uma comunidade econômica.

Neste mesmo ano foi assinado em Montevideu o tratado que deu origem à Associação Latino-Americana de Livre-Comércio (ALALC), em que participaram inicialmente Argentina, Brasil, Chile, México, Paraguai, Peru e Uruguai. Com a posterior incorporação de Colômbia, Equador, Venezuela e Bolívia, a ALALC compreendia no final do decênio todos os países sul-americanos, à exceção das Guianas, mais o México. No entanto, esta associação foi concebida no espírito do GATT (General Agreement on Tariffs and Trade), seja do ponto de vista dos seus objetivos, de liberalizar as trocas na região em lugar de constituir uma união aduaneira, como pelos seus processos operacionais, que consistiam em negociações bilaterais produto por produto. Furtado anota que esta associação traduziu antes "uma resposta a problemas limitados surgidos em torno do comércio dos países meridionais, do que propriamente uma abertura no sentido de estruturar em bases novas as relações econômicas entre os países da região" (Furtado, 1986: 262).

A mediocridade dos resultados iniciais produzidos por esta iniciativa provocou um processo de subregionalização, materializado na criação do Grupo Andino em 1969 composto por Bolívia, Chile, Colômbia, Equador e Peru, com a posterior adesão da Venezuela em 1973. A percepção dos desafios envolvidos na aproximação de economias de proporções díspares, como é o caso de Brasil, Argentina e México em relação aos demais países da região estimulou esta aproximação, que tinha em vista uma liberalização automática e irreversível do comércio. No bojo deste movimento foi criado a Corporación Andina de Fomento (CAF), primeiro órgão financeiro multinacional exclusivamente latino-americano.

Além deste impulso de natureza econômica à integração regional, em resposta aos impasses da industrialização substitutiva de importações, o triunfo da Revolução Cubana em 1959 elevou a problemática da solidariedade internacional no continente a um novo patamar, em ambos polos do espectro político. Ao acirrar as tensões entre revolução e contrarrevolução que marcaram a Guerra Fria, o processo cubano teve um impacto político e ideológico extraordinário no continente, explicitando a dimensão política da questão regional. Refletindo o aceleramento da história que caracterizou esta conjuntura, o horizonte revolucionário que se descortinava incidiu na teoria social progressista, em um contexto caracterizado por íntimos nexos entre o trabalho intelectual e a prática política: "La revolución cubana hizo importantes contribuciones a la teoría social, pero estas no aparecieron en forma de artículos o libros científicos, ni su influencia se hizo sentir directamente en los medios académicos. En forma indirecta, a través de asembleas, mítines, discursos, revistas y periódicos militantes, de los manifiestos y declaraciones, la Revolución Cubana cambió el clima ideológico de las ciencias sociales latinoamericanas" (González Casanova, 2006: 
Premido pela intransigente agressividade dos Estados Unidos, a rápida radicalização do processo cubano explicitou a unidade entre os conteúdos nacional e democrático da revolução, problematizando a viabilidade histórica de afirmar a nação na América Latina nos marcos do capitalismo. Na esfera política, a hostilidade permanente sofrida por este processo no âmbito da OEA (Organização dos Estados Americanos) evidenciou a conduta servil dos estados latino-americanos diante dos Estados Unidos, expressão da unidade de interesses que aproximava as classes dominantes à potência hegemônica na região ${ }^{5}$.

$\mathrm{O}$ acirramento da luta de classes nesta conjuntura se materializou no afloramento ou revigoramento de movimentos guerrilheiros em todo o continente, que o Estado cubano procurou incentivar por meio da OLAS (Organização Latino-Americana de Solidariedade), ao mesmo tempo em que ditaduras militares assumiram o comando da repressão política e social em diversos países, com apoio explícito dos Estados Unidos. Esta regionalização da luta de classes contribuiu para projetar o dilema da formação nacional em um horizonte continental, em um contexto em que a solidariedade entre os repressores, cujas expressões paradigmáticas foram a Escola das Américas e a Operação Condor, correspondia à intensificação da presença de multinacionais de capital estadunidense na região, acirrando os impasses vivenciados pelo processo de substituição de importações.

Por outro lado, a solidariedade entre os que resistiam à repressão, na luta armada ou no exílio, estimulou uma aproximação política que teve expressão paradigmática na trajetória de Che Guevara. No plano teórico, proliferaram análises de escopo continental que, em resposta à radicalização da conjuntura, sugeriam a unidade do conteúdo democrático e socialista da revolução latino-americana. A corrente mais radical da teoria da dependência, expressa neste momento em autores como André Gunder Frank, Rui Mauro Marini, Aníbal Quijano e Luis Vitale (Kay, 1989), assim como análises heterodoxas como as de Rodolfo Stavenhagen, Orlando Fals Borda ou Florestan Fernandes (Stavenhagen, 1965; Fals Borda, 1968; Fernandes, 1972), entre outros, além dos documentos de numerosos partidos e organizações revolucionárias da época, apontam para esta convergência entre nação, socialismo e unidade continental (Löwy, 2003).

Assim, a sucessão de golpes militares que assolou o continente na esteira da Revolução Cubana ensejou uma radicalização teórica no campo da esquerda, uma vez que se explicitavam os constrangimentos sociais e políticos enfrentados por projetos referidos ao nacional-desenvolvimentismo e à própria CEPAL, além dos limites da política prevalente entre os partidos comunistas da região. A progressiva penetração de capitais estadunidenses acenava com uma via para aprofundar a industrialização alternativa à democratização social e à regionalização da substituição de importações, elidindo a problemática da estagnação, enquanto a cumplicidade das classes dominantes com os regimes instaurados colocava em xeque a noção de uma burguesia nacional que instrumentalizasse o Estado para um projeto de nação.

No plano teórico, a crítica aos postulados cepalinos e ao comunismo ortodoxo ensejou respostas de sentido político oposto referidas à problemática da dependência, que maturou com destaque no Chile, em dois espaços críticos que abrigavam numerosos exilados: os seminários realizados no Instituto Latino-Americano de Planejamento Econômico e Social (ILPES), nos quais participaram, entre outros, Celso Furtado, Francisco Weffort, Fernando Henrique Cardoso, José Medina Echevarría, Osvaldo

\footnotetext{
${ }^{5} \mathrm{O}$ precedente desta situação foi a conduta da OEA ao longo do processo guatemalteco, analisada em: Gleijeses, 2004.
} 
Sunkel e Pedro Vuskovic, e também em torno do Centro de Estudos Socioeconômicos (CESO) da Faculdade de Economia da Universidade do Chile, onde atuaram André Gunder Frank e os brasileiros Ruy Mauro Marini, Theotônio dos Santos e Vânia Bambirra (Hadler, 2013: 33).

Por um lado, difundiram-se reflexões fora do marco teórico que associava desenvolvimento a integração nacional, consagrado pela CEPAL desde Raúl Prebisch. A obra "Dependência e desenvolvimento na América Latina", de Enzo Faletto e Fernando Henrique Cardoso, é paradigmática desta inflexão (Cardoso e Faletto, 1969). Em linhas gerais, os autores sugeriram que, diante do movimento de internacionalização do mercado interno decorrente da progressiva penetração de capitais estrangeiros, seria possível conciliar o interesse das multinacionais ao desenvolvimento industrial no continente. Alinhada a uma perspectiva que consagra a separação analítica entre os problemas da marginalidade e da acumulação capitalista, reivindicada por Tavares e Serra em sua crítica a estagnação econômica vislumbrada por Furtado no Brasil (Tavares \& Serra, 1970), os autores entendem que, em um cenário de solidariedade entre o capital internacional e o espaço econômico nacional, os problemas de realização associados à estreiteza do mercado interno e à marginalidade social não obstam o desenvolvimento. Nas palavras de Cardoso, "dependência, capitalismo monopolista e desenvolvimento não são termos contraditórios, pois ocorre um tipo de desenvolvimento capitalista dependente nos setores do Terceiro Mundo que estão integrados na nova forma de expansão monopolista"(Cardoso, 1975: 195).

Assim, a partir de uma ótica que reduz a problemática do desenvolvimento ao grau de diferenciação do sistema produtivo, envolvendo avanços na divisão do trabalho e no progresso tecnológico, a reflexão de Cardoso e Faletto aliena as dimensões nacional e democrática desta problemática, prenunciando uma inflexão ideológica que atingiria a própria CEPAL nos anos seguintes, quando a hegemonia neoliberal consumaria a dissociação entre crescimento econômico e nação na América Latina (Rodríguez, 1981).

A problemática da dependência foi problematizada de modo diverso por um conjunto de autores que inclui André Gunder Frank, Aníbal Quijano e Luis Vitale, além de Teotônio dos Santos, Vania Bambirra e Ruy Mauro Marini, cujos trabalhos servem como referência original para uma teoria marxista de dependência. A despeito de nuances políticas e ideológicas, o denominador comum entre estes autores radica no ensejo de criticar, no plano teórico, a noção de um feudalismo latino- americano e da existência de uma burguesia nacional anti-imperialista, e no plano político, a proposição de uma via nacional-democrática para a revolução no continente. Enfatizando a singularidade das formações sociais latino-americanas e a natureza dependente do seu desenvolvimento capitalista, estas análises convergem em indicar o socialismo como a via necessária para a superação do subdesenvolvimento. Theotonio dos Santos enuncia a ambição teórica desta corrente quando, remetendo ao conceito de consciência possível de Lucáks, afirma que todas as classes sociais do continente se movem nos marcos do pensamento da classe hegemônica, angulado entre o desenvolvimentismo e o nacionalismo (Dos Santos, 2011 (1978): 344). O mesmo autor sintetiza sua relação com a tradição marxista na seguinte passagem: "El estudio del desarrollo del capitalismo en los centros hegemónicos dio origen a la teoría del colonialismo y del imperialismo. El estudio del desarrollo de nuestros países debe dar orígen a la teoría de la dependencia" (Dos Santos, 2011 (1978): 357). A crítica à CEPAL e à ortodoxia comunista são evidentes, assim como a reivindicação de um instrumental analítico

próprio. 
Ruy Mauro Marini está entre os autores que desenvolveram um arsenal teórico sob esta perspectiva, em diálogo crítico explícito com a abordagem à problemática da dependência delineada por Cardoso. Preso e torturado por sua militância revolucionária no Brasil, Marini estabeleceu-se no Chile e posteriormente no México, onde produziu a maior parte de sua obra. Seu ponto de partida é a percepção de que a superexploração do trabalho constitui um elemento fulcral da reprodução capitalista em contexto de dependência, na medida em que compensaria a baixa produtividade do trabalho com uma elevada extração de mais-valia absoluta. Nesta perspectiva, a marginalidade social é questão estrutural que responde a uma racionalidade econômica específica, e não uma distorção episódica que pode ser equacionada por uma política desembaraçada de interesses reacionários da sociedade nacional, como é o caso das ditaduras na visão de Cardoso (Marini 2000; 2013).

$\mathrm{Na}$ interpretação de Marini, a perpetuação da superexploração do trabalho redunda em óbices para a realização capitalista, bloqueando os nexos entre acumulação e circulação. Entretanto no caso brasileiro, ao contrário de conduzir a uma estagnação, o enfrentamento destes entraves intensifica uma tendência à concentração e centralização de capitais, que leva o país a ingressar na fase monopolista do capitalismo, desencadeando um movimento de exportação manufatureira, disputa de mercados regionais e militarização do Estado, descrito pelo autor como "subimperialismo".

Portanto para Marini, o golpe militar no Brasil foi uma resposta da burguesia em um contexto de crise econômica, expressa em bloqueios à acumulação e realização do capital, em um momento em que a polarização da luta de classes ameaçava os pilares da superexploração do trabalho e a própria dominação estadunidense na região. Coerente com uma abordagem que salienta a especificidade do movimento capitalista periférico, o sociólogo brasileiro rechaça a leitura de que as ditaduras são impostas pelos Estados Unidos, realçando a racionalidade burguesa subjacente a uma manobra destinada a solucionar a contradição entre produção e consumo. Ao contrário de Cardoso, que sublinha o peso do mercado interno, Marini atribui os nexos do capital estrangeiro com o espaço econômico nacional às possibilidades de rentabilidade excepcional ancorada na superexploração do trabalho, que no entanto, precisa se expandir regionalmente em função da especificidade do ciclo do capital dependente, nos marcos de uma "cooperação antagônica" com os Estados Unidos. A peculiaridade deste arranjo é realçada na seguinte passagem: "O capitalismo brasileiro se orientou, assim, rumo a um desenvolvimento monstruoso, posto que chega à etapa imperialista antes de ter conquistado a transformação global da economia nacional e em uma situação de dependência crescente frente ao imperialismo internacional. A consequência mais importante desse fato é que, ao contrário do que ocorre nas economias capitalistas centrais, o subimperialismo brasileiro não pode converter a espoliação que pretende realizar no exterior em um fator de elevação do nível de vida interno, capaz de amortecer o ímpeto da luta de classes. Em vez disso, devido a sua necessidade de proporcionar um sobrelucro a seu sócio maior estadunidense, tem que agravar violentamente a exploração do trabalho nos marcos da economia nacional, no esforço para reduzir seus custos de produção" (Marini, 2013 (1969): 157).

A centralidade da superexploração do trabalho para a reprodução do capitalismo dependente implica em uma incompatibilidade estrutural entre desenvolvimento das forças produtivas, democracia burguesa e Estado de Bem-Estar Social, em oposição à perspectiva de Cardoso, que considera circunstancial a violência desencadeada pelas ditaduras. Em suma, se Cardoso não identifica contradição entre dependência, 
capitalismo monopolista e desenvolvimento, Marini entende que superexploração do trabalho e marginalidade social são indissociáveis do capitalismo dependente.

A despeito das diferenças teóricas e políticas entre estes dois intérpretes, e o diálogo crítico que estabelecem com a tradição cepalina e a ortodoxia comunista, observa-se um esforço comum a todas estas expressões, orientado a interpretar a história e a conjuntura latino-americana em uma perspectiva de conjunto. Este empenho parte da premissa de uma origem compartilhada no fenômeno colonial, apontando para um devir político homólogo, no caso de Cardoso, ou orientado à integração, na visão cepalina ou de Marini. Pois embora este último faça uma leitura negativa das tendências integracionistas sob a égide do "subimperialismo brasileiro", indica ao mesmo tempo que "a internacionalização da revolução latino-americana aparece como a contrapartida inevitável do processo de integração imperialista, em sua nova fase inaugurada pelo golpe militar brasileiro" (Marini, 2013 (1969): 132).

Assim, por um lado ou por outro, observa-se que há uma correspondência entre a centralidade da propositura integracionista para a intelectualidade progressista latinoamericana, e a importância desta temática para os governos da região, principalmente no plano econômico, constatada por Furtado no final dos anos 1960: "A formação de um mercado comum regional constitui hoje em dia um objetivo declarado de política econômica de todos os governos latino-americanos" (Furtado, 1986: 267).

Retrospectivamente, sabemos que as iniciativas nesta direção tiveram um alcance limitado. O experimento centroamericano ficaria comprometido a partir da guerra entre Honduras e El Salvador em 1969, enquanto as proposições sulamericanas sofreram as consequências da inflexão política que, afinal, prevaleceu no subcontinente. Neste sentido, se a ideia avançada por Marini de que o golpe militar brasileiro inaugurou uma nova fase do processo de integração imperialista desperta controvérsias, é difícil não concordar com a sugestão de que o golpe militar chileno, sete anos mais tarde, consumou um movimento contrarrevolucionário em escala continental.

No final dos anos 1960, os impasses concretos que o nacionaldesenvolvimentismo encontrava conheceram provas políticas práticas na experiência do Gobierno Revolucionario de las Fuerzas Armadas, comandado por Velasco Alvarado no Peru a partir de 1968, e sob o governo da Unidad Popular no Chile, eleito dois anos depois. Anunciado "como el primer gobierno de la CEPAL" na América Latina (Cotler, 1984: 410), o projeto liderado por Alvarado pretendeu suprir a ausência de uma burguesia nacional por meio de um Estado comandado pelos militares, que impôs uma agenda nacionalista e progressista também motivada, com certa ambiguidade, pelo receio da insurgência popular. Subjacente a este processo estava a crença, endossada pela CEPAL, de que "desde y a partir del nuevo estado se podría formar la nación" (Cotler, 1984: 411).

Por outro lado, o projeto da Unidad Popular contagiou corações e mentes na esquerda mundial com a proposta de construir o socialismo a partir da institucionalidade legada, em oposição à via armada: a "via chilena ao socialismo". A convergência entre nação, socialismo e unidade continental indicada por numerosos intelectuais e organizações de esquerda nos anos 1960, encontrou tradução concreta nesta efêmera experiência. No plano regional, ao alinhar-se sem ambiguidades à revolução cubana, o programa da Unidad Popular no Chile vinculou nacionalismo e antiimperialismo à necessidade de refundar os marcos institucionais em que se articulavam os países latinoamericanos: "A posição de defesa ativa da independência do Chile implica na denúncia da atual OEA como instrumento e organização do imperialismo norte-americano e na luta contra qualquer forma de pan-americanismo implícita nessa organização. $O$ 
Governo Popular providenciará a criação de um organismo realmente representativo dos países latino-americanos" (Programa, 1970: 111).

Processo político que sintetizou as esperanças de uma geração, a derrocada do governo comandado por Salvador Allende (1970-1973) assinalou em seu momento a derrota de um horizonte civilizatório, que apontava para a convergência entre nação e socialismo, referida a uma aproximação entre os povos do continente. A explicitação do caráter antidemocrático, antipopular e antinacional das classes dominantes com a onda repressiva que assolou o continente, condenou o nacional-desenvolvimentismo e como decorrência, a possibilidade da nação em marcos burgueses. O processo peruano então em curso naufragaria pouco depois, e em seguida, a Argentina ingressaria na ditadura mais repressiva que conheceu.

Ao desmanche do ideário nacional-desenvolvimentista, em que pese a recorrente afirmação de nacionalismos de caserna que mal disfarçavam o sentido antinacional das políticas implementadas, correspondeu o esfacelamento das proposições embrionárias de integração regional. Lembremos que o Chile comandado por Pinochet, pioneiro na adesão ao neoliberalismo, foi também o primeiro a se retirar do Pacto Andino em 1977, para não mencionar o apoio à Inglaterra durante a Guerra das Malvinas em 1982. A inserção internacional atual do Chile, alinhada a países que privilegiam tratados bilaterais e acordos de livre-comércio em oposição aos esforços de integração regional, remete a este período traumático da sua história e aos constrangimentos impostos à redemocratização neste país, que sucessivos governos socialistas foram incapazes de superar. Por outro lado, o fracasso da integração regional comprometeu a própria industrialização, conduzindo os países da região a uma grave crise econômica que se evidenciou na década de 1980, marcada por estagnação econômica, crises cambiais e hiperinflação.

No plano intelectual, as férteis sendas teóricas abertas pela teoria marxista da dependência, entre outras correntes que apontavam para uma convergência entre nação, socialismo e integração regional foram silenciadas, por vezes literalmente ${ }^{6}$. Assim, a derrota dos projetos de integração regional, vislumbrados como resposta de sentido democrático aos limites da industrialização por substituição de importações, deve ser entendida como uma dimensão do movimento contrarrevolucionário que se impôs no continente neste período.

4.

Projetos de integração regional voltaram ao debate político continental nos anos 1990, no contexto da formação de blocos econômicos nos marcos da concorrência intracapitalista após o colapso soviético. Nesta perspectiva, a derrota dos projetos democrático-nacionais na América Latina no curso da Guerra Fria também deve ser interpretada como um capítulo da derrota política que facultou a escalada neoliberal no mundo, evidente de modo paradigmático no desenlace da experiência chilena (Klein, 2008).

Em um movimento que se confunde com a própria globalização, a aceleração das tendências à financeirização do capitalismo pressionou por uma abertura econômica multilateral, associada à difusão da agenda política identificada com o neoliberalismo,

\footnotetext{
${ }^{6}$ Para dar um exemplo concreto, mais além das perseguições e assassinatos do período: a Revista Mexicana de Sociologia publicou uma crítica de Fernando Henrique Cardoso às concepções de Marini escrita em parceria com José Serra, em seu número extraordinário de 1978, que também trouxe a resposta de Marini. No Brasil, a Revista Estudos do Cebrap circulou somente o primeiro artigo e a resposta de Marini só foi publicada em 2000 em coletânea editada por Emir Sader. Ver: Marini, 2000.
} 
em um processo cuja racionalidade reforçou a liderança geopolítica dos Estados Unidos, ao menos em um primeiro momento ${ }^{7}$. Expressão regional deste movimento, a constituição do NAFTA (North American Free Trade Agreement) e da UNASUL (União Sul-americana de Nações), iniciativas a que se refere Bethell, está referida a este contexto adverso às forças populares, cujas linhas gerais é preciso reconstituir.

Em 1990, no momento em que se desmanchava a União Soviética, o presidente George Bush lançou a "Iniciativa para as Américas", uma proposta de integração regional balizada pelo tripé livre comércio, fluxo de investimentos e pagamento da dívida externa, prevendo uma integração comercial hemisférica, excluindo Cuba. Em 1994, na $1^{\text {a }}$ Cúpula das Américas em Miami a proposta ganhou corpo, substanciando-se no projeto da ALCA (Área de Livre-Comércio das Américas), que deveria ser implementada até 2005. Simultaneamente, entrou em vigor um acordo de livre comércio entre Estados Unidos, México e Canadá em 1994, o NAFTA. Entretanto, a proposta da ALCA enfrentou resistências do estado e de amplos setores da sociedade no Brasil e em outros países latino-americanos. Também nos Estados Unidos não houve consenso político em acordar autonomia à presidência para agilizar as negociações, favorecendo manobras da diplomacia brasileira que resultaram no fracasso da iniciativa, consumado na V Cúpula das Américas em 2005 (Teixeira, 2011).

A partir de então, os Estados Unidos adotaram como estratégia a assinatura de tratados bilaterais de livre-comércio, firmando acordos com países centro-americanos, Chile, Colômbia e mais recentemente, o Peru, ao mesmo tempo em que aprofundaram as dimensões que lhe interessavam na integração regional, principalmente relacionadas à segurança, por meio de iniciativas como a ASPAN (Aliança para a Segurança da América do Norte). Se o NAFTA e seus desdobramentos são identificados com uma integração subordinada, unanimemente condenada pelo campo popular no continente ${ }^{8}$, o processo que levou a constituição da UNASUL está associado a um movimento de sentido diverso, apesar de controvérsias que devem ser ponderadas.

Ao consumar-se o atrelamento da política mexicana aos Estados Unidos em meados dos anos 1990, a diplomacia brasileira visualizou progressivamente a América do Sul como referência geográfica de um projeto de liderança regional. Esta perspectiva materializou-se em uma aproximação entre o Mercosul (Mercado Comum do Sul) e a CAN (Comunidade Andina das Nações), como uma estratégia para a constituição de um bloco econômico alternativo no espaço sul-americano. É neste contexto que surgiu durante o governo de Fernando Henrique Cardoso, a proposta da IIRSA (Iniciativa para a Integração da Infraestrutura Regional Sul-americana), sinalizando para uma integração sul-americana referenciada no que a CEPAL descreveu neste momento como um "regionalismo aberto" - uma modalidade de integração regional orientada à abertura comercial multilateral ${ }^{9}$.

Originalmente pensada como a dimensão de infraestrutura deste projeto de integração regional, proposta em uma cúpula de presidentes sul-americanos em Brasília em 2000, o governo Lula procurou ressignificar a IIRSA em consonância com as diretrizes da sua política externa. Com a constituição da UNASUL em 2008, a iniciativa

\footnotetext{
${ }^{7}$ Ver a respeito: Brenner, 2003; Gowan, 2003; Panitch \& Gindin, 2006. Para uma visão de conjunto do processo na América Latina, consultar: Arceo \& Basualdo, 2006; Borón, 2008; Martins, 2011.

${ }^{8}$ Uma boa análise a respeito é: Arroyo Picard, 2009.

9 A IIRSA prevê um conjunto de projetos de integração da infraestrutura regional, nas áreas da comunicação, energia e transporte. Em seu relatório de 10 anos constavam 524 projetos, com investimento estimado em 96 bilhões de dólares distribuídos em 47 grupos pertencentes a 9 Eixos de Integração e Desenvolvimento (IIRSA, 2011). Uma síntese das críticas originais a iniciativa é: Bartesaghi; Ceroni;

Díaz, 2006.
} 
se converteu no esteio material desta organização, efetivamente incorporada ao Conselho de Infraestrutura e Planejamento (COSIPLAN) da UNASUL em 2011. Para justificar este movimento, os defensores da gestão petista indicam uma inflexão na orientação da política externa brasileira, que teria abandonado o regionalismo aberto característico dos anos anteriores em nome de uma política que enfatiza a integração sul-americana como estratégia de inserção internacional soberana, descrita como "regionalismo desenvolvimentista" ou "pós-liberal". Nesta perspectiva, sugere-se que esta modalidade de integração promoverá "a integração física entre os interiores dos países, passo fundamental para a integração de cadeias produtivas de fornecedores e produtores relacionados, objetivando a formação de economias de escala e a própria integração das sociedades sul-americanas" (Desiderá Neto \& Teixeira, 2012: 32).

No entanto, esta proposição tem sido problematizada por diversos conflitos socioambientais envolvendo a expansão da presença das empreiteiras brasileiras no continente, apoiada na atuação controversa do BNDES, o que levou um analista a descrever a IIRSA como uma espécie de "PAC (Programa de Aceleração do Crescimento) para a América do Sul” (Novoa Garzón: 2011). No plano teórico, ressurgem reflexões que resgatam, de modo explícito ou não, as proposições de Rui Mauro Marini nos anos 1970, ressignificando o que este autor descreveu como um "subimperialismo brasileiro" (Fontes, 2012; Luce, 2007; Zibechi, 2012).

Mais além de eventuais contradições políticas e inconsistências teóricas, o sentido geral destas contestações sugere um Estado a serviço da expansão de determinados setores capitalistas nacionais na América do Sul, como as empreiteiras e o agronegócio, por meio de uma modalidade de integração voltada à constituição de corredores de exportação de commodities, tais como a soja, o etanol e minérios e que aponta, em última análise, para uma reprimarização da economia do subcontinente sob a liderança regional brasileira, funcional ao movimento do capitalismo contemporâneo. Assim, a polêmica em torno ao caráter da IIRSA redunda, em última análise, em uma apreciação sobre o sentido das gestões presidenciais petistas no Brasil.

Os paradoxos envolvidos na atuação regional brasileira se evidenciaram na crise que culminou na deposição do presidente Fernando Lugo no Paraguai em 2012. Primeira alternância de poder após mais de meio século de dominação colorada, incluindo quatro décadas de ditadura stronista (1954-1989), a eleição de Lugo acendeu esperanças de avanços sociais, principalmente na questão agrária, e foi identificada na região com o campo progressista. No entanto, encarando um congresso dominado por proprietários rurais, o governo enfrentou desde o início uma intransigente oposição. Entre os ruralistas, o setor mais dinâmico do agronegócio paraguaio é a soja, que viveu uma extraordinária expansão nos últimos quinze anos comandada por empresários de origem brasileira, alcunhados como "brasiguaios", com apoio do governo brasileiro e do $\mathrm{BNDES}^{10}$. Este setor tem notórios vínculos com os colorados que, segundo analistas, articularam a chacina de Curuguaty que serviu de pretexto para depor o presidente, em um processo que o governo brasileiro tentou evitar (Méndez, 2012; Nickson, 2012). Assim, o dilema paraguaio expressou um paradoxo da influência brasileira na região, na medida em que o apoio ao empresariado rural brasiguaio enrijeceu os óbices enfrentados pelo governo Lugo para avançar ações mínimas de democratização do

\footnotetext{
10 "En mayo de 2007, la visita del Pdte. Lula en el marco del Seminario de Agrocombustibles BrasilParaguay, concluyó con la firma del memorándum de entendimiento. El presidente brasileño estuvo acompañado de 30 empresarios y los alentó a que invirtieran en el Paraguay. El Banco Nacional de Desarrollo Económico y Social (BNDES) de Brasil, anunció en dicho Seminario que contará con una línea de crédito específica para financiar a empresarios brasileños que decidan invertir en agronegocios en Paraguay."

(BASE

IS, 2010: 
acesso à terra, enfraquecendo sua posição diante de interesses que desencadearam um processo de impeachment que a diplomacia brasileira foi então, impotente para frear.

5.

Ao romper com o escopo continental de propostas de integração regional pretéritas, a constituição do NAFTA e da UNASUL atestam, segundo Bethell, a inutilidade do conceito de América Latina na atualidade. Assim, o argumento do historiador inglês tem como premissa uma redução das possibilidades históricas de integração, assumindo como definitivos dois movimentos de integração regional em curso: um protagonizado pelos Estados Unidos, que a partir do estabelecimento do NAFTA em 1994 procura cimentar sua influência regional por meio de iniciativas em conluio com o estado mexicano, como o Plan Puebla-Panama, o Plan Merida e a ASPAN, ao mesmo tempo em que assina tratados bilaterais de livre-comércio com países da região, enfraquecendo as possibilidades de uma iniciativa latino-americana alternativa. Outro capitaneado pelo Brasil, substanciado em um projeto de integração sul-americana que ganhou corpo a partir da eleição de Lula em 2002, e recebeu expressão política mais elaborada com a constituição da UNASUL em 2008.

A despeito da controvérsia sobre o sentido desta integração protagonizada pelo Brasil, é possível deduzir que uma iniciativa reunindo as antípodas políticas no subcontinente na atualidade, Colômbia e Venezuela, está mais próxima de ser uma organização "guarda-chuva", como advoga o Brasil, do que uma alternativa ao modelo neoliberal, como defendia Chávez - propositor, diga-se de passagem, da ALBA (Aliança Bolivariana para as Américas), como uma via de integração diversa e de escopo continental (Sanahuja, 2012). Iniciativas unionistas com este sentido não contradizem necessariamente os interesses dos Estados Unidos na região, que pretendem instrumentalizar estes organismos em consonância com sua própria agenda, como revela pronunciamento de Hilary Clinton em uma conferência da OEA em Lima no ano de 2010: "Nós acreditamos que é do interesse nacional dos Estados Unidos e de todas as nações aqui representadas promover a colaboração pragmática e produtiva entre os membros da comunidade das Américas. É por isso que damos as boas-vindas a parcerias multilaterais como a UNASUL, o CARICOM e a SICA, e ao objetivo do Conselho Sul-Americano de Defesa (que é integrado à UNASUL) de promover uma maior confiança entre seus membros e uma cooperação mais efetiva para assegurar a segurança em relação ao crime organizado e ao terrorismo" (Clinton, 2010) ${ }^{11}$.

Como processos políticos em curso, é arriscado prever o sentido em que evoluirão iniciativas como NAFTA e UNASUL. Considerando o seu caráter controverso e em disputa, endossá-las ideologicamente como faz Bethell significa apoiá-las politicamente, o que é legítimo. Mas isso não as converte na palavra final da história sobre o tema, como a própria fundação da Comunidade de Estados LatinoAmericanos e Caribenhos (CELAC) no ano seguinte à publicação do texto do historiador inglês, sugere.

\footnotetext{
11 "We believe it is in the national interest of the United States and of every nation represented here to promote pragmatic and productive collaboration among members of the community of the Americas. That is why we welcome multilateral partnerships like UNASUR and CARICOM and SICA and the South American Defense Council's goal of promoting greater confidence among its members and more effective cooperation to ensure security from organized crime and terrorism."
} 


\section{O Brasil na América Latina, ontem, hoje e amanhã}

Após resgatar as motivações na origem de um projeto de unidade continental, analisando a evolução histórica de seu conteúdo, retomarei o diálogo com a segunda proposição de Bethell, problematizando a pertinência de pensar o Brasil como parte de uma totalidade designada como "América Latina" no século XXI diante dos processos de integração regional em curso acima descritos.

Minha análise se baseará em três premissas subjacentes ao argumento desenvolvido até este momento. Primeiramente, saliento a historicidade do conceito de América Latina, apontando que seu significado e conteúdo político evoluem em consonância com o movimento da história continental. Por sua vez, o sentido deste movimento resulta de uma disputa política, em que a dinâmica da luta de classes local e mundial se entrelaça. Em outras palavras, a vitalidade e o conteúdo político de um projeto de integração regional está relacionado à correlação de forças entre as classes sociais, em âmbito nacional e internacional. Assim, o panamericanismo de James Blaine está nas antípodas políticas da nuestra América de José Martí, assim como a ALBA de Hugo Chávez se gestou em oposição explícita à ALCA de Bush, embora as quatro propostas expressem modalidades de integração regional. Como corolário das proposições anteriores, a atualidade do conceito de América Latina no Brasil e nos demais países do continente revela-se uma questão politicamente densa, relacionada não somente à leitura que se faz do movimento da história contemporânea e à correlação de forças entre os atores sociais, mas sobretudo, ao horizonte civilizatório que se projeta para o continente. A implicação deste corolário é que, entre a proposição de Bethell e a minha não há quem esteja certo ou errado abstratamente. O que se constata são premissas ideológicas diferentes que nos colocam, em relação a esta questão, em campos políticos opostos.

A partir destas considerações gerais, que se aplicam a todos os países latinoamericanos, resumirei minha leitura sobre a singular relação política e ideológica entre o Brasil e a América Latina nas linhas seguintes.

Vimos que o projeto de unidade continental foi avançado originalmente no contexto das guerras de independência hispano-americanas como um instrumento político visando afiançar a soberania dos novos países, diante do risco de intervenção europeia. Ocorre que na emancipação do Brasil, em contraste com a América Espanhola continental, prevaleceu a negociação pactuada em lugar do confronto militar, de modo que o novo país vivenciou o paradoxo de ser governado por um príncipe português. Nesta conjuntura singular, o risco de uma intervenção europeia não esteve no horizonte político da monarquia escravocrata, que se afirmou como bastião conservador no continente.

Em meados do século XIX, quando surge o conceito de América Latina em resposta às tensões decorrentes do expansionismo estadunidense na direção de México, América Central e Caribe, o Brasil tampouco tinha razões para temer a projeção continental daquele que era seu principal aliado na resistência às pressões inglesas pelo fim da escravidão, a despeito de projetos inconsequentes de anexação da Amazônia instigados por filibusteiros, nos moldes daqueles praticados ao norte do estreito de Darién (Moniz Bandeira, 1998: 87-95).

Na virada do século (XIX-XX) a difusão das relações de produção capitalistas no contexto do imperialismo e a intervenção ianque na guerra de independência cubana, seguida de sucessivas invasões na região nos primeiros decênios do século, convergem para um aggiornamento da utopia de unidade continental, sempre em oposição aos Estados Unidos. Para além de pregadores incisivos porém sem base social, como o 
argentino Manuel Ugarte, a repercussão das revoluções mexicana e bolchevique instigou a difusão de um sentimento antiimperialista, bem como do ideário comunista e do materialismo histórico, em um contexto de aceleradas transformações socioeconômicas. Ressoando às reformas universitárias iniciadas em Córdoba em 1918 e à simpatia despertada pela resistência de Sandino na Nicarágua no final dos anos 1920, constituíram-se organizações referidas a um ideário latino-americanista em países diversos como Peru, Cuba e Argentina.

E o Brasil nesta conjuntura? No final do século XIX o país já tinha produzido ao menos uma obra de destaque crítica aos Estados Unidos, o livro de Eduardo Prado, "A ilusão americana" (Prado, 2001). Escrita à sombra da interferência ianque no episódio conhecido como a Revolta da Armada em 1893, que ameaçou o governo de Floriano Peixoto e a própria república, a obra está orientada pelo ideário monarquista, podendo ser classificada como reacionária e evidentemente, não tinha como horizonte a integração continental. Longe de excepcional, este livro ilustra as dificuldades para se afirmar uma tradição política progressista em um país recém egresso da escravidão, e dominado pelo conservadorismo. É em reação a esta situação, que contrasta com outros países latino-americanos, que Antonio Candido reivindica um estatuto político transformador para aqueles que descreveu como intelectuais "radicais" no Brasil: "Podese chamar de radicalismo, no Brasil, o conjunto de ideias e atitudes formando contrapeso ao movimento conservador que sempre predominou. Este conjunto é devido a alguns autores isolados que não se integram em sistemas, pois aqui nunca floresceu em escala apreciável um corpo próprio de doutrina politicamente avançada, ao contrário do que se deu em países como o Uruguai, Peru, México e Cuba" (Candido, 1990).

Em minha opinião, é sobre este pano de fundo que devem ser apreciadas as visões sobre a América Latina produzidas no Brasil no início do século XX, algumas das quais foram abordadas na tese de doutorado de Katia Gerab Baggio (Baggio, 1998). Chama a atenção que, entre os diversos intelectuais analisados (Eduardo Prado, Oliveira Lima, Manuel Bomfim, José Veríssimo, Euclides da Cunha, Joaquim Nabuco, Artur Orlando e Sílvio Romero), nenhum deles possuiu vínculo orgânico com um movimento que pode ser considerada progressista. Aqueles que não estão no campo conservador, aproximam-se da situação de "autores isolados que não se integram em sistemas" referida por Candido, como é o caso de Manuel Bomfim ou Euclides da Cunha.

Assim, o limitado impacto do movimento pela reforma universitária que eclodiu em Córdoba em 1918 deve ser entendido como parte deste quadro geral: embora um abrangente estudo sobre o episódio identifique alguma repercussão no Brasil uma década mais tarde, materializada no movimento tenentista (Portantiero, 1978), o fato é que em 1918 o Brasil simplesmente não tinha universidades ${ }^{12}$. Foi na Argentina que Luis Carlos Prestes, expressão máxima da radicalização tenentista nos anos seguintes, aprofundou seu conhecimento sobre o marxismo, ao final da épica empreitada que ficou conhecida com o seu nome - a "Coluna Prestes" - na qual seus comandados percorreram parte do Brasil, antes de refugiaram-se em países vizinhos.

Como em outros países do continente, a percepção de que o Brasil partilhava de um legado histórico e de dilemas políticos comuns a seus vizinhos maturou em consonância com o processo de industrialização substitutiva de importações, que evidenciou, em uma palavra, o fenômeno do subdesenvolvimento. É a percepção da dimensão econômica da dependência, em um contexto em que a hegemonia geopolítica

\footnotetext{
${ }^{12}$ A primeira universidade brasileira propriamente dita foi criada por iniciativa do governo federal no Rio de Janeiro em 1920, aglutinando as escolas Politécnica, de Medicina e de Direito já existentes. No âmbito estadual, em 1912 reuniram-se no Paraná a Escola de Engenharia, a Faculdade de Medicina e a Faculdade de Direito, dando origem à Universidade do Paraná.
} 
estadunidense se projeta ao sul do Canal do Panamá, que instiga a integração latinoamericana como um horizonte político para o Brasil. Porém, este não é um movimento imediato: é significativo que Caio Prado Junior (1907-1990) e Nelson Werneck Sodré (1907-1990), provavelmente os intelectuais comunistas de maior projeção do país cuja militância floresceu neste contexto, não tenham tematizado a América Latina em sua prolífica obra.

Como vimos, o esgotamento da substituição de importações nos anos 1960 estimulou proposições de integração regional de motivação econômica, enquanto a repressão estatal apoiada pelos Estados Unidos aos movimentos de orientação democrática-nacional generalizou a dimensão política da solidariedade continental. Neste momento, é significativo o número de intelectuais críticos brasileiros que pensam a América Latina, muitos dos quais foram também militantes exilados, como Celso Furtado (1920-2004), Darcy Ribeiro (1922-1997), Florestan Fernandes (1920-1995), Octavio Ianni (1926-2004), Theotonio dos Santos (1936), Vania Bambirra (193?-2015), entre outros. O escopo e os termos em que se deu a controvérsia entre Fernando Henrique Cardoso (1931) e Ruy Mauro Marini (1932-1997), analisada anteriormente, expressam este movimento. No entanto, a mera constatação de que este pensamento matura principalmente no exílio, revela que se trata de uma perspectiva que está sendo derrotada. E mais do que derrotada, está sendo banida.

O fim das ditaduras no Cone Sul nos anos 1980 significou uma democratização limitada, caracterizada por continuidades políticas, econômicas e sociais. No caso brasileiro, o caráter pactuado da transição resultou em um pleito indireto que elegeu como presidente um político da oposição tolerada pela ditadura, Tancredo Neves. Falecido antes mesmo de tomar posse, assumiu o cargo um quadro da oligarquia nordestina do país que presidira o partido situacionista da ditadura, aquela à qual Neves fez oposição: o vice-presidente José Sarney.

Os constrangimentos à democratização política, ilustrados de modo patético pelo caso brasileiro, se traduziram em um acanhamento para enfrentar os graves problemas sociais e econômicos legados, entre a carestia e a inflação. O padrão de enfrentamento destas questões levou a uma progressiva subordinação da política econômica dos países da região aos ditames de organismos multilaterais, notadamente o Fundo Monetário Internacional (FMI). O resultado foi um percurso em que, em linhas gerais, a dívida externa serviu como um garrote para impor políticas antitéticas ao nacionaldesenvolvimentismo, enquanto a inflação legitimou programas de estabilização monetária que essencialmente, converteram os países mais prósperos da região em plataformas de valorização do capital financeiro, além do costumeiro papel de exportador de matérias-primas. Assim, o chamado receituário neoliberal redundou em uma perversa engrenagem de dependência permanente do afluxo de capital especulativo para compensar balanças comerciais cada vez mais deficitárias, o que por sua vez, exige uma remuneração extraordinária a estes capitais (os maiores juros do planeta, no caso brasileiro) e garantias políticas incondicionais, sob pena de um incremento no "riscopaís" avaliado por agências privadas que podem provocar uma fuga de capitais, colocando tudo a perder. Foi este o sentido da "Carta aos brasileiros" divulgada pela candidatura de Lula da Silva em 2002, em um momento em que avaliou-se necessário assegurar às finanças que a iminente vitória do líder sindicalista não ameaçaria a nação como um negócio.

Paradoxalmente, a eleição de Lula despontou como resposta ao acentuado desgaste político daqueles que promoveram a agenda neoliberal no país, mas os que conduziram o Partido dos Trabalhadores ao executivo nacional entenderam que era preciso acatar os parâmetros legados para viabilizar a eleição, e depois, a gestão. E depois, a reeleição. E assim sucessivamente.

Novamente, a situação brasileira ilustra um padrão recorrente no subcontinente, onde a alternância política mal disfarçou os constrangimentos legados pelas ditaduras, intensificados com a difusão das políticas neoliberais no continente. Como decorrência, observou-se um desgaste generalizado de partidos tradicionais, que abriu espaço para a 
eleição de novas figuras políticas, como Chávez na Venezuela (1999); Morales na Bolívia (2006); Correa no Equador (2007); Lugo no Paraguai (2008). Ou para o triunfo de candidatos identificados com a esquerda, como Tabaré Vazquez no Uruguai (2006), Maurício Funes pelo Frente Farabundo Martí em El Salvador (2009) e o próprio Lula da Silva no Brasil (2003). A despeito das credenciais radicais de alguns destes líderes, prevaleceram governos nos marcos do que foi descrito como izquierda consentida (Webber \& Carr, 2013), caracterizados pela complacência em relação ao neoliberalismo.

É este o contexto regional em que ressurgiu um projeto de integração subcontinental liderado pelo Brasil. No plano internacional, como vimos, a formação de blocos econômicos regionais responde a uma racionalidade mercantil acentuada pela globalização. Assim, o governo Lula não iniciou este movimento, como a própria constituição da IIRSA indica, mas pretendeu conceder-lhe uma orientação distintiva, coerente com um ensejo de projeção internacional do país marcado pelas limitações do seu horizonte político, que retomaremos adiante. É possível argumentar que a ênfase sul-americana em detrimento de projetos de alcance continental seja uma delas.

Neste ponto cumpre relembrar que, do ponto de vista das correntes democráticas latino-americanas, a integração regional nunca foi vista como um fim em si, mas como um meio para enfrentar a dupla articulação entre assimetria social e dependência externa. Nesta perspectiva, assim como um setor expressivo da sociedade mexicana não se resignou diante do NAFTA, os brasileiros que se opõem ao neoliberalismo devem denunciar qualquer modalidade de integração regional balizada pelos negócios, e não pela solidariedade entre os povos. Neste contexto, a afirmação de laços de identidade regional, em contraste com ideologias e estereótipos que reforçam o estranhamento, milita na segunda direção. A noção de que o Brasil faz parte da América Latina é parte deste embate.

\section{Desafios, perspectivas e horizontes da integração continental}

Reivindicada a atualidade política da integração continental, e reconstituídas as linhas gerais deste movimento na atualidade, bem como alguns dos seus limites, me concentrarei nesta seção em delinear as determinações gerais que devem fundamentar, na minha leitura, um projeto integracionista de sentido emancipador.

Um processo de integração regional na América Latina e no Caribe orientado a superar a articulação entre dependência e assimetria social deve assumir como premissa teórica e política a singularidade da formação social e econômica da região. Seu 
principal traço distintivo em relação aos países centrais é a permanência do legado colonial, que se expressa na orientação fundamentalmente extroversa da sua base econômica, apesar do avanço na industrialização e no adensamento do mercado interno em diversos países.

Esta constatação traz duas consequências políticas. Em primeiro lugar, uma formação histórica original exige propostas de integração regional próprias. Em particular, esquemas transplantados das experiências europeias revelam-se inadequados à realidade continental, uma vez que partem de um conjunto de sociedades nacionais relativamente mais integrados, mais desenvolvidos do ponto de vista das forças produtivas e menos heterogêneos no plano social. Projetos integracionistas que reneguem a premissa da especificidade latino-americana arriscam-se a reeditar debates análogos àqueles que informaram o campo intelectual democrático no século $\mathrm{XX}$, como o mito do "take off" avançado por W. W. Rostow (Rostow, 1974), que motivou a pesquisa de Celso Furtado sobre a formação econômica brasileira e latino-americana. Ou como a polêmica em torno da existência de um feudalismo latino-americano, e a consequente pertinência de alianças políticas entre comunistas e setores antiimperialistas e antioligárquicos das burguesias locais como vetor de uma revolução democrática nacional (Assadourian; Cardoso; Ciafardini, 1973).

Estes debates constituíram momentos fundamentais para a maturação de um pensamento social e econômico assentado na especificidade histórica da região, processo que foi interrompido violentamente com a afirmação de regimes repressivos em grande parte do continente, mesmo onde não houve ditaduras militares ${ }^{13}$. O impacto desta derrota foi decisivo para criar as condições políticas e intelectuais de uma dissociação entre a problemática do desenvolvimento e a afirmação da nação, entendida em sua dupla dimensão de soberania e integração democrática. Este descolamento culminou na ortodoxia neoliberal, que procura legitimar uma inversão, na qual a sociedade aparece subordinada aos dinamismos da economia. De acordo com esta ideologia, problemas como o índice de inflação ou a taxa de crescimento são vistos como um fim em si, e não como um instrumento da integração nacional e regional.

Porém, o desgaste decorrente da implementação deste receituário antipopular acelerou o desprestígio de partidos políticos convencionais, possibilitando a eleição de numerosos governantes latino-americanos que se projetaram em reação ao neoliberalismo. A despeito das opções controversas que diversos destes presidentes fizeram uma vez eleitos, esta sinalização inequívoca de rechaço à ortodoxia neoliberal permitiu importantes frestas ao pensamento crítico e à política radical na América Latina, que buscam por diferentes caminhos reestabelecer a conexão entre o legado do pensamento social e econômico autóctone e os dilemas civilizatórios contemporâneos, expresso em noções como "Sumak Kawsay" (ou "Buen Vivir") e "Socialismo do Século XXI". À possibilidade de projetos políticos inovadores corresponde o ressurgimento de um horizonte integracionista de sentido emancipador, em torno de proposições como a ALBA, a UNASUL e a CELAC.

A segunda decorrência política do reconhecimento da orientação fundamentalmente extroversa da economia do subcontinente aponta para a precariedade das bases materiais de um projeto integracionista. Parte-se de uma estrutura produtiva constituída, desde o período colonial, nos marcos de uma integração subordinada ao mercado mundial como exportador de produtos primários. De modo correspondente, a infraestrutura de transportes, comunicação e energia desenvolvida no contexto da industrialização está referenciada pelo imperativo de conectar os polos produtores de

\footnotetext{
${ }^{13}$ Basta lembrar o massacre de Tlatelolco no México em 1968 e as políticas repressivas adotadas por Colômbia e Venezuela face à emergência guerrilheira.
} 
gêneros de exportação a seus escoadouros logísticos no litoral. Já no final do século XIX, José Martí salientava as dificuldades inerentes a um projeto integracionista nesta circunstância, ao analisar os entraves enfrentados por Simón Bolívar: " Acaso, en su sueño de gloria, para la América y para sí, no vio que la unidad de espíritu, indispensable a la salvación y dicha de nuestros pueblos americanos, padecía, más que se ayudaba, con su unión en formas teóricas y artificiales que no se acomodaban sobre el seguro de la realidad (...) se revelaba el desacuerdo patente entre Bolivar, empeñado en unir bajo un gobierno central y distante los países de la revolución, y la evolución americana, nacida, con múltiples cabezas, del ansia del gobierno local y con la gente de la casa propia!" (Martí, 2000: 282, tomo 3).

Historicamente, os níveis de troca intrarregional são baixos, uma vez que prevalece a redundância entre as bases produtivas nacionais em lugar da complementariedade, impondo a concorrência entre os diferentes países, em lugar da cooperação. Sem dúvida, esta é uma situação decorrente da dificuldade dos países da região em assumir o controle sobre o próprio destino e que se expressa, de um lado, na perpetuação de vínculos de dependência característicos da relação centro-periferia, e de outro, na impotência para estabelecer relações de colaboração regional. Esta questão é agravada por sua expressão cultural, uma vez que prevalecem influências ideológicas e vínculos políticos e acadêmicos com os países do centro, em detrimento do conhecimento mútuo e da cooperação intelectual intracontinental. Ao contrário de ser um fenômeno restrito às classes dominantes, remetendo à identificação do negro como inferior e do aborígene como bárbaro que dominou o pensamento latino-americano até o início do século XX, esta questão perpassa todos os estratos sociais na atualidade, onde abundam a desinformação, os preconceitos e as animosidades nacionais.

O que estas constatações sugerem é que a integração latino-americana não está inscrita na evolução econômica da região, à maneira como o desenvolvimento das forças produtivas geraria as condições materiais para o socialismo, ao agudizar a contradição entre o caráter social da produção e sua apropriação privada. Isto porque o movimento da história tem reafirmado, a despeito de significativas mudanças inerentes à própria evolução histórica da região, a articulação entre dependência e superexploração do trabalho, para utilizar termos caros a Marini. E com isso, se reproduzem as determinações gerais que obstam a integração regional nas diferentes esferas: econômica, política, e cultural. Em consonância com este movimento, realizamse modalidades de integração limitada à esfera mercantil, que respondem a interesses corporativos multinacionais, cuja escala de atuação lhes convida a planejar sua própria expansão em escala regional. Como já anotou Furtado em relação à experiência da ALALC, "tais sistemas podem conduzir a formas de "integração" que prescindem de centros nacionais de decisão, ou tendem a esvaziar estes" (Furtado: 1986, 267).

Sentido inverso deve ter um processo de integração emancipador da América Latina e do Caribe. Partindo de uma trajetória econômica adversa, esta proposição deve ser, fundamentalmente, um projeto político emanado do movimento histórico destas sociedades, que incorpore a integração regional como necessidade inelutável para superar a condição dependente. Embora a análise de Abelardo Ramos sobre a "nação latino-americana" publicada em 1968 incorra em anacronismo, evocando uma "unidade essencial" do continente que considero problemática, sua conclusão converge com este enfoque: "Fica evidente, pelo que foi dito, que a unidade da América Latina não se postula hoje como exigência do desenvolvimento das forças

\footnotetext{
${ }^{14}$ FURTADO, Celso. A economia latino-americana. São Paulo: Companhia Editora Nacional, 1986, p. 267.
} 
produtivas na busca do grandioso mercado interno das vinte repúblicas, mas sim, justamente, pela razão oposta. Para nos lançarmos decididamente no caminho da civilização, da ciência e da cultura, e exatamente para desenvolver o potencial econômico de nossos povos, seja pela via capitalista, por meio do capitalismo de Estado, pela rota de um socialismo crioulo ou por uma combinação de todas as opções mencionadas, a América Latina precisa se unir para não se degradar. Não é o progresso do capitalismo, como aconteceu na Europa ou nos Estados Unidos, o que exige, hoje, a unidade de nossos estados, mas sim a crise profunda e o esgotamento da condição semicolonial que padecemos" (Abelardo Ramos, 2012 (1968): 551).

No século XXI a unidade latino-americana revela-se como premissa necessária, embora insuficiente, para salvaguardar a região das tendências desagregadoras que caracterizam o capitalismo contemporâneo, em que tem crescido a concentração de renda, o empobrecimento das massas, a precarização do trabalho, a expropriação camponesa, o desemprego, a criminalidade urbana, o narcotráfico, a homogeneização cultural, a xenofobia, a ameaça ecológica, entre outras mazelas sociais. Em outras palavras, a integração regional reemerge como parte de um processo que podemos descrever como uma revolução latino-americana, orientado a assumir o controle sobre o próprio destino, subordinando o progresso econômico aos anseios e necessidades do conjunto da população.

Nesta perspectiva, a integração regional tem como motor a articulação entre processos de mudança social nacionais, que incorporem a unidade continental como uma necessidade histórica. $\mathrm{O}$ fortalecimento dos centros nacionais de decisão e da sua capacidade de planejamento econômico na forma do Estado nacional é uma premissa para o estabelecimento de laços orgânicos de cooperação regional, em contradição com a lógica da integração corporativa. Pois como lembra Mariátegui, é inviável articular nações incompletamente formadas, afinal "la nación precede a toda sociedad de naciones" (Mariátegui, 1990: 14). Na atualidade, nação, unidade continental e resistência à barbárie se articulam.

A proposição de que a unidade latino-americana em uma perspectiva emancipatória só se realizará nos marcos de processos de mudança social que se articulem em escala continental, materializando a "revolução latino-americana" de que fala Marini, recoloca em questão o problema do ator político da transformação social. Embora o desenlace dos impasses enfrentados pela substituição de importações tenha sido interpretado por diversos intelectuais críticos, como o próprio Marini, como uma evidência da inviabilidade da via burguesa para a nação, os processos progressistas em curso no continente tem enfrentado óbices de natureza objetiva e subjetiva para radicalizarem-se nesta direção.

De um lado, a corrosão dos instrumentos tradicionais da política classista face ao impacto do neoliberalismo, como os sindicatos e partidos operários, debilitaram a base material de projetos revolucionários referenciados à classe operária como tal. Este fenômeno mundial foi potencializado pelo fim da União Soviética, que facultou uma ulterior ofensiva política e ideológica neoliberal, sintetizada na noção do fim da história.

Por outro lado, observa-se a emergência de novos atores políticos, organizados principalmente como movimentos sociais. Entre os zapatistas no México, os sem-terra no Brasil e os piqueteros na Argentina, os resultados políticos mais impressionantes foram alcançados por movimentos de extração camponesa e identidade indígena na Bolívia e no Equador, onde quatro presidentes foram derrubados no início do século XXI. Na Bolívia, na esteira de uma notável sequência de insurreições populares, foi 
eleito como presidente um líder cocalero de origem aimará, enquanto no Equador, triunfou um agudo crítico à atuação das instituições financeiras multilaterais.

Inspirados no processo venezuelano desencadeado com a eleição de Hugo Chávez em 1999, nestes dois países escreveram-se novas constituições, na qual a influência dos movimentos indígenas se evidenciou principalmente na instituição do Estado Pluri-Nacional no caso boliviano, e na figura jurídica inédita dos "direitos da natureza" no Equador. Em ambos países, a constituição consagrou o princípio aborígene do "Sumak Kawsay", apontando para uma sociabilidade contrária à mercantilização da riqueza e da vida. Já no caso venezuelano, houve uma progressiva radicalização em resposta à intransigência das classes dominantes locais, manifesta no golpe frustrado de 2002. Em termos ideológicos, este movimento se revelou na incorporação de uma retórica anti-imperialista em 2003, conducente à proposição de um socialismo bolivariano ventilado a partir de 2004, que alguns descreverão como "socialismo do século XXI", e que se adensará com a proposição do Estado Comunal de 2006 em diante.

Deixando de lado controvérsias em relação à natureza destes processos, que na Venezuela e no Equador se autodenominam como revolucionários, nos três casos constatam-se entraves objetivos para uma política baseada na classe operária, na medida em que são países de escassa industrialização. No caso venezuelano, uma economia um pouco mais industrializada, as particularidades da constituição do sindicalismo nacional, vinculado ao Pacto de Punto Fijo e particularmente à AD (Acción Democratica), resultaram em uma central sindical opositora ao governo. No entanto, nos três países emergiram proposições de orientação anticapitalista: o socialismo bolivariano na Venezuela e o princípio constitucional do Sumak Kawsay na Bolívia e no Equador. Nos três casos mobilizam-se tradições políticas próprias do continente, entre heróis nacionalistas (Simón Rodríguez, Simón Bolívar e Ezequiel Zamora) e as culturas nativas.

Embora o processo venezuelano seja onde mais se avançou na direção da mudança, o princípio do Sumak Kawsay ilumina de forma direta impasses civilizatórios que se projetam para a problemática da integração regional. Ao advogar um padrão de relação do homem com a natureza que não seja "antropocêntrico", exigindo que se incorpore a preocupação ecológica como condição da reprodução humana, nem "desenvolvimentista", na medida em que aponta para um padrão civilizatório que não está centrado no desenvolvimento das forças produtivas, esta noção problematiza o progresso como referência de um horizonte revolucionário (Dávalos, 2008). Mais além dos embates correntes na sociedade equatoriana, onde a questão ecológica atingiu um alto grau de politização, culminando na inovadora porém derrotada proposta de manter inexploradas as reservas de petróleo no Parque Nacional Yasuní mediante aportes financeiros da comunidade internacional (Acosta, 2009), o princípio do Sumak Kawsay levanta duas questões importantes relacionadas à integração regional.

Em primeiro lugar, este princípio sintetiza um rechaço popular ao que se convencionou denominar nos países andinos como "extrativismo", entendido como um padrão de desenvolvimento alicerçado na exploração de riquezas naturais para exportação. Se por um lado esta crítica indica o desígnio de superar a condição de exportador primário mediante uma diversificação produtiva baseada na industrialização, ela também sugere uma rejeição a um padrão de desenvolvimento ancorado no crescimento econômico, percebido como conducente à concentração da riqueza e à reprodução das desigualdades sociais. Esta segunda dimensão crítica se articula, na proposição do Sumak Kawsay, a um rechaço generalizado do que poderíamos sintetizar, 
nos termos de Marx, como a "sociedade das mercadorias". Em suma, sugere-se um padrão civilizatório alternativo, ancorado na realidade material e cultural andina, em que o consumismo característico das sociedades contemporâneas seria subordinado a um ideal humanista de integração com a natureza.

Projetada regionalmente, a oposição ao extrativismo associada ao Sumak Kawsay sugere uma rejeição à racionalidade que preside a proposta de integração subjacente à IIRSA, defendida pelas gestões petistas. Em última análise, a crítica ao extrativismo indica uma negação da herança colonial e da perpetuação de uma lógica de ocupação e exploração territorial alheia ao interesse dos seus habitantes. Em seu polo positivo, este ideário reivindica o legado aborígene como fonte de inspiração política e ideológica de um projeto civilizatório alternativo, condizente com a realidade regional, no qual as determinações do desenvolvimento econômico se subordinam aos anseios e necessidades do conjunto da população.

Este não é um enfoque inédito no pensamento crítico latino-americano. Problematização análoga foi feita por ao menos dois intelectuais em momentos históricos e realidades nacionais diferentes, a partir de ângulos diversos, mas que se debruçaram sobre o problema da integração contintental. No final do século XIX, José Martí sugeriu desde Cuba um rechaço ao "odio de clases" que caracterizava as sociedades ocidentais, acenando com um caminho civilizatório próprio, angulado em torno das noções de "hombre natural" e "equilibrio del mundo". Quase um século mais tarde, Celso Furtado problematizou a reprodução de padrões de consumo do centro capitalista em sociedades periféricas, onde a estreita base produtiva exige uma concentração de renda como condição para a realização capitalista. A partir desta perspectiva, o economista brasileiro fez uma crítica aguda ao "mimetismo cultural" das classes dominantes na América Latina, indicando a impossibilidade de conciliar padrões de consumo importados e integração da população através do trabalho. É relevante observar que nestes três ideários está ausente a dimensão de classe do problema do civilizatório, salientado pela tradição socialista. Portanto, fica em aberto a questão: é possível forjar uma sociabilidade alternativa nos marcos do capitalismo dependente?

A despeito deste limite, vislumbram-se por meio dos problemas suscitados em torno do Sumak Kawsay, que ressoam questões levantadas por gerações anteriores de pensadores radicais no continente, algumas dimensões necessárias de um projeto de integração emancipador. É preciso subordinar o desenvolvimento econômico aos interesses do conjunto da população, o que à luz da problemática ecológica no século XXI, implica em questionar o paradigma civilizatório ancorado na noção de progresso. Isso não significa rejeitar os avanços da civilização industrial, como Martí e Furtado nunca fizeram, mas sim subordinar meios a fins, para usar uma terminologia weberiana. Em linhas gerais a integração da América Latina, assim como o socialismo, é uma utopia de abundância que aponta para o futuro, mas que não faz escala em Miami, ou seja: é preciso adequar o padrão de consumo às bases materiais das sociedades periféricas, o que envolve uma descolonização cultural e uma reorientação produtiva que rompa com a concentração e o privilégio, em favor da integração social. Em suma, trata-se de controlar o ritmo, o tempo e a orientação da inovação social. Andar com as próprias pernas, a passos que sejam do tamanho delas, em uma direção do interesse comum.

Evidentemente tratam-se de tarefas hercúleas, que exigem um trabalho político de longo prazo. A equação entre as necessidades do desenvolvimento econômico e o imperativo ecológico não é simples, nem consensual na esquerda. Na prática política presente, redunda frequentemente em um dilema entre razão de estado e ideologia, ilustrado de forma lapidar na declaração do presidente Correa no Equador, ao dizer que 
"no podemos ser mendigos sentados en un saco de oro"15. No plano da integração regional, esta tensão é exemplificada pelos conflitos em torno à construção da rodovia atravessando o Parque Nacional TIPNIS na Bolívia, e à hidroelétrica de Inamburi no Peru, ambos projetos de interesse do Estado brasileiro, realizados por empreiteiras brasileiras, e paralisados na atualidade em função de intensa resistência popular.

Os dilemas em torno do caráter do desenvolvimento econômico em sociedades de industrialização atrasada permearam os processos revolucionários contemporâneos. No debate soviético dos anos 1920, a disjuntiva se colocou entre a industrialização acelerada às expensas do campesinato, defendida por Preobrazhensky, ou o chamado "passo de tartaruga" advogado por Bukharin, sugerindo um avanço industrial relativamente mais lento, mas sem sacrificar a economia camponesa. Como se sabe, a "acumulação primitiva socialista" se concretizou com a coletivização forçada do campo, em um processo que consumou a ruptura da base popular da revolução, embora tenha atingido seu objetivo material imediato. Na conjuntura soviética o paradigma do progresso era unânime, associando socialismo a desenvolvimento das forças produtivas, entendido como um modo de produção economicamente superior em um contexto anterior à emergência da questão ecológica. Sem entrar no mérito desta discussão, importa salientar que, retrospectivamente, a opção de priorizar o aspecto econômico da revolução, identificado com o desenvolvimento das forças produtivas em detrimento da sua dimensão política, parece ter custado a própria revolução, que não foi vitoriosa no terreno que escolheu para dar combate.

Não quero sugerir que o capitalismo é um modo de produção mais eficiente do que o socialismo, porque não é o que eu penso, e endereçar essa questão implicaria em discutir a natureza do processo soviético ${ }^{16}$. Simplesmente aponto que, ao aceitar o paradigma de progresso prevalente em todas as suas dimensões, desde o desenvolvimento das forças produtivas até a corrida espacial, passando pelas zonas de influência geopolítica e a disputa olímpica, a experiência soviética pouco avançou em diferenciar seu horizonte civilizatório daquele prevalente no capitalismo central. Derrotado no terreno da concorrência econômica, sua base de sustentação política ruiu. E uma das decorrências do seu colapso foi a reversão do significativo processo de integração regional subjacente à constituição da União das Repúblicas Socialistas Soviéticas.

Entendo que a integração latino-americana deve construir um outro horizonte civilizatório, que tenha como valores fundamentais a autodeterminação econômica, a soberania política, a integração social e a autorreferência cultural. Nesta perspectiva, a generalização do padrão de consumo estadunidense não pode servir como referência, porque é economicamente inviável, ecologicamente irresponsável e culturalmente indesejável.

Esta proposição indica que a cultura é um dos terrenos em que se disputa o sentido da integração latino-americana. Porque é preciso difundir a consciência de que a democratização é contraditória com o privilégio, em todas as suas dimensões ${ }^{17}$. Portanto na América Latina, onde o sofisticado padrão de consumo dos países centrais é privilégio de poucos, a integração social só é possível às expensas deste mimetismo cultural. A modernização dos padrões de consumo no capitalismo periférico é incompatível com o controle sobre o ritmo e o tempo da inovação social, que por sua vez, é uma premissa para inverter a inserção internacional subordinada, rompendo a

\footnotetext{
${ }^{15}$ Enfoques distintos sobre estes dilemas em: Gudynas, 2010: 61-81; Borón, 2008: 170-206.

${ }^{16}$ Perspectivas diferentes encontram-se em: Mészaros, 1996; Blackburn, 2005.

${ }^{17}$ Em última análise, é contraditória com o próprio capitalismo segundo Wood (Wood, 2011).
} 
articulação entre dependência e desigualdade. Em outras palavras, a soberania é premissa da igualdade, que só é possível se referida à realidade econômica e cultural do continente.

Estas proposições indicam a necessidade de um esforço contínuo e de longo prazo no sentido de desmontar o que Gramsci chamou como "senso comum", construindo uma visão contra-hegemônica sobre o horizonte civilizatório do continente. Este esforço tem três dimensões principais.

Primeiramente, como já mencionado, é preciso explicitar a incompatibilidade entre integração do conjunto da população através do trabalho e padrões de consumo copiados dos países centrais. Nas antípodas do mito do crescimento econômico, a democratização do consumo exige uma adequação da estrutura produtiva às necessidades do conjunto da população, em um movimento que contradiz a modernização dependente. É preciso explicitar os nexos entre modernização dos padrões de consumo e concentração de renda, mostrando sua relação antitética com o ensejo de controle sobre o espaço econômico e a igualdade social. Em suma, é necessário evidenciar que, no atual momento histórico, é preciso optar entre modernização e concentração, ou soberania e democratização.

Uma segunda dimensão, que decorre da primeira, é a importância da descolonização cultural. Esta proposição, que é mais fácil dita do que feita, tem múltiplas implicações desde o padrão de consumo até a teoria social, passando pelo racismo e as referências culturais. Longe de ser um fenômeno restrito às classes dominantes, a admiração das expressões culturais do capitalismo central e dos Estados Unidos em particular, é um fenômeno que perpassa todas as classes sociais e também diferentes espectros políticos, embora em diferentes graus de intensidade.

A outra face deste fenômeno é um sentimento de inferioridade em relação ao que é nativo. Por isso, o ponto de partida para enfrentar o colonialismo cultural é a valorização do que é próprio em todas as suas dimensões, o que envolve um reconhecimento da especificidade continental. Não se trata somente de uma questão de fundo humanístico, reivindicando-se o estatuto civilizatório de diferentes culturas, mas é uma questão política central em um horizonte de autodeterminação. Porque os valores fundamentais pelos quais se avalia o êxito de uma empreitada latino-americanista serão outros, referidos à autonomia e à democratização, e possivelmente, ao equilíbrio ecológico e à realização das potencialidades humanas. Nesta perspectiva, a cabeça dos latino-americanos deve estar onde seus pés pisam.

A terceira dimensão de um esforço contra-hegemônico aponta para uma conscientização sobre as determinações históricas que irmanam o destino dos países latino-americanos. A despeito dos óbices econômicos, históricos e culturais para a integração continental, o movimento da história contemporânea em direção à internacionalização da produção e à financeirização do capital, ao qual corresponde a formação de blocos regionais, torna ainda mais improvável a superação dos dilemas comuns em escala nacional. Em uma palavra, a unidade continental reemerge no século XXI como uma necessidade histórica.

Esta percepção é mais fácil em países de economia de enclave, nos quais a dominação internacional sempre foi mais evidente, e o nacionalismo e o antiimperialismo maturaram como ideários políticos de base popular, como recorre na América Central e no Caribe. Na América do Sul, a necessidade de integração regional para superar os entraves à industrialização foi particularmente sensível nos países andinos, em função da escala diminuta de suas economias. Assim, não é casual que a eleição de governos progressistas na Venezuela, Bolívia e Equador foi acompanhada de esforços de sentido integracionista. No entanto, em toda a região é necessário promover a solidariedade continental como um valor, identificado com a superação da inserção internacional periférica e das mazelas sociais acentuadas por esta condição. 
Um exemplo concreto da articulação entre as dimensões econômica e cultural da problemática do desenvolvimento é o drama característico da formação venezuelana, que desafia o processo bolivariano na atualidade, em meados de 2015: a abundância de divisas decorrente da receita petroleira provoca fenômenos econômicos associados à "doença holandesa", em que a valorização da moeda nacional enseja a importação e obsta a diversificação produtiva. Nas palavras de um líder camponês no país, os venezuelanos estão acostumados a "colher no porto". Assim, uma das dimensões do desafio histórico de "sembrar el petroleo" retomado pelo processo bolivariano, está relacionado à generalização de uma expectativa de consumo descolada das potencialidades produtivas nacionais. E o outro lado da dependência de importações é uma maior vulnerabilidade do ponto de vista do abastecimento e do controle cambial, testemunhadas pelo presidente Maduro. Seguramente, esta é uma das motivações que pressionou o governo Chávez na direção de propostas inovadoras de integração regional, materializadas na ALBA em 2004.

A trajetória de aceitação e rejeição a esta iniciativa ilustra outros problemas que enunciamos. Atraindo a adesão dos países andinos que tem apostado na integração regional em oposição ao livre-comércio, Bolívia e Equador, a ALBA também conta com a participação de Cuba, Nicarágua e algumas ilhas caribenhas: Antígua e Barbuda, Dominica, Granada, São Cristóvão e Nevis, Santa Lucia, São Vicente e as Granadinas. O acesso facilitado ao petróleo venezuelano, potenciado com a criação da Petrocaribe em 2005' tem sido um atrativo importante para estas ilhas, assim como para a Nicarágua. Também Honduras interessou-se em somar-se ao bloco em 2008, em uma conjuntura em que a crise internacional impactou sobre a economia local. Análises apontam que este foi um elemento central para desencadear o movimento golpista que destituiu o presidente Manuel Zelaya em junho de 2009, episódio emblemático da resistência entre as classes dominantes do continente a projetos de potencial anti-imperialista (Gordon \& Webber, 2013).

Estas resistências se evidenciam ulteriormente na análise da situação brasileira. Possivelmente, uma adesão deste país daria um peso diferente à ALBA em nível global, fato que não se concretizou. Conforme descrevemos anteriormente o país optou, sob a liderança do Partido dos Trabalhadores, por uma política focalizada na América do Sul, na qual o interesse de setores concentrados do capitalismo brasileiro se mesclam à ambição diplomática de fazer do Brasil um protagonista da política internacional, ou um global player. Nesta perspectiva o país buscou, simultaneamente, fortalecer o Mercosul como um bloco econômico e fazer da UNASUL uma organização regional, de cunho eminentemente político. Como decorrência, em lugar do Brasil ingressar na ALBA, foi a Venezuela que aderiu ao Mercosul. E neste país como nos demais, o termo "bolivarianismo" foi demonizado, em lugar de indicar a opção por uma política soberana e original, orientada à integração regional. Enquanto isso, uma iniciativa proposta por Caracas para mitigar esta e outras difamações, a criação da Telesur, não foi apoiada pelo governo brasileiro.

No entanto, em que pese sua moderação, a orientação sul-americana da política externa do Partido dos Trabalhadores tem sido vigorosamente criticada por setores identificados com a oposição liberal. Contestando a relevância concedida ao Sul em geral e à América do Sul em particular como espaço privilegiado de expansão da influência política e econômica brasileira, esta crítica está fundamentalmente assentada em uma racionalidade mercantil, ponderando que os ônus da integração regional superam os bônus. A noção cunhada pelo diplomata tucano Rubens Barboza de uma "diplomacia da generosidade", acusando o governo brasileiro de concessões 
desvantajosas ao interesse nacional em temas relacionados ao gás boliviano e à hidroelétrica de Itaipú, por exemplo, ilustra esta posição.

Porém, observa-se uma convergência em relação à importância de avançar obras de infraestrutura promovendo a integração continental. Assim, a IIRSA é defendida por diplomatas que se situam nos marcos do regionalismo aberto, como José Gonçalves Botafogo, quem se queixa de que a iniciativa "tem sido pouco prestigiada, quando talvez seja a instituição que mais dinamismo possa dar a integração sul-americana", e defende a prática de uma "diplomacia infraestrutural”(Botafogo, 2013).

No que tange ao Mercosul, a análise de Vigevani constatou tensões entre a tradição autonomista e universalista da diplomacia brasileira, e os requisitos necessários para aprofundar a integração regional. Em última análise, este autor identifica ambiguidades no comportamento do estrato social que identifica como "elites", em que o desígnio de liderar a integração regional confronta-se com receios em arcar com os custos políticos e econômicos que este compromisso implica, resultando em limitações no escopo e alcance deste processo (Vigevani et al, 2008). A resistência a bancar o envolvimento brasileiro no Mercosul foi sintetizado de modo lapidar pela ex-assessora da missão brasileira na Organização Mundial do Comércio (OMC), Vera Thorstensen. Perguntada sobre com quais países o Brasil deveria fazer acordos comerciais, respondeu: "Com os grandes, não adianta casar com pobre"(Thorstensen, 2014).

As críticas de Barboza e Thorstensen na situação brasileira iluminam dois desafios inerentes à integração regional em perspectiva emancipadora. O primeiro deles, já delineado anteriormente, é que o motor deste processo precisa ser um projeto político determinado a superar a articulação entre dependência e superexploração do trabalho. Calcado em uma racionalidade estritamente econômica, a integração regional tende a se referenciar no interesse de conglomerados multinacionais atuantes no subcontinente, reforçando assimetrias sociais e regionais em um processo funcional, em última análise, à reprodução da divisão internacional do trabalho prevalente. Considerando que o papel histórico da região está vinculado ao provimento de matérias-primas, o processo integracionista é vulnerável às oscilações dos preços mundiais destes produtos, enquanto o escasso domínio da inovação tecnológica o expôe à volubilidade das multinacionais, que privilegiam a saúde das matrizes, sobretudo em momentos de crise. Em suma, se projetada em confluência e não em contradição com o movimento do capital internacional, a integração tende a avançar nos momentos de prosperidade, e a recuar em tempos da crise.

Isso não significa dizer que considerações econômicas tenham interesse secundário para a integração regional, mas sim que, no processo de subordinar o movimento da economia às necessidades do conjunto da população, a política direcionará a economia, e não o contrário. Pois uma integração de sentido emancipador deve transcender acordos de livre-comércio ou a interconexão infraestrutural visando constituir, como observou Furtado trinta anos atrás, um autêntico sistema econômico regional: "Admite-se, presentemente, como mais ou menos evidente, que, longe de ser simples questão de liberalização de comércio, o verdadeiro problema consiste em promover a criação de um sistema econômico regional, o que não será tarefa pequena, em razão da orientação anterior do desenvolvimento, dos riscos de agravamento da concentração geográfica tanto das atividades econômicas como da apropriação dos frutos do desenvolvimento, da considerável autonomia com que atuam na região poderosos consórcios internacionais, que controlam não somente atividades de exportação tradicionais, mas também grande parte do setor manufatureiro moderno, das divergências entre as políticas nacionais no controle e orientação dos processos econômicos e de outros fatores de não menor importância" (Furtado, 1986: 267-8).

De notável atualidade, estas considerações salientam um segundo aspecto levantado pelas posições de Barboza e Thorstensen, relacionado às consideráveis disparidades regionais com que se defronta qualquer projeto de integração na região. 
Encarada sob um prisma estritamente mercantil desde a maior economia do subcontinente, a integração pode ser vista como interessante, na medida em que propicie bons negócios a setores capitalistas referidos, em alguma medida, ao espaço econômico nacional. Ou pode ser percebida negativamente, avaliando-se que os prejuízos superam os ganhos. No entanto, em ambos cenários se impõe uma visão instrumentalizadora dos países vizinhos, de seu mercado, de seus recursos naturais e de sua força de trabalho. É preciso assinalar que uma integração de sentido emancipador não pode ser pautada pela lógica da concorrência econômica e da dominação política, mas deve se orientar pela busca do bem comum, privilegiando a cooperação econômica e a solidariedade política, respeitando-se o direito à autodeterminação dos povos. Uma diplomacia da generosidade deve ser assumida e praticada com altivez na região, principalmente pelo Brasil, cultivando um casamento a ser selado não somente por dinheiro, mas também por amor.

Evidentemente, há nexos entre a necessidade de se constituir um autêntico sistema econômico regional e os valores que devem orientar este desígnio, na medida em que ambos vetores implicam em ceder algum nível de autonomia nacional em nome de um projeto de alcance maior. Neste sentido, preconceitos e ressentimentos históricos, que não são poucos entre os países da região, precisam ser superados em prol de um internacionalismo latino-americano, projetado como o alicerce ideológico de um projeto emancipador.

2.

Até que ponto as iniciativas de integração regional em curso, notadamente a UNASUL e a CELAC, representam avanços em uma direção emancipadora?

Traduzida em termos de classe, a análise de Vigevani abordando o Mercosul com foco no Brasil explicita uma vulnerabilidade dos projetos em andamento, hipoteticamente referidos a um regionalismo desenvolvimentista. Analisada do ponto de vista de sua própria racionalidade, esta proposição supõe uma burguesia identificada com um projeto nacionalista, baseado em um protagonismo regional que tende a reproduzir as assimetrias que caracterizam historicamente a região, a despeito de esforços ainda modestos em direção contrária, como o Fundo para a Convergência Estrutural do Mercosul (FOCEM) (Mello e Souza; Oliveira; Gonçalves, 2010). Esta percepção reproduz desconfianças recíprocas, principalmente entre Argentina e Brasil, amplificadas com gosto pela mídia corporativa. Por outro lado, conforme ilustram as posições de Barboza e Thorstensen, esta proposição tem se mostrado incapaz de solidificar um consenso mínimo entre as classes dominantes brasileiras, desdobrando-se em resistências a assumir os custos políticos e econômicos da integração regional. $\mathrm{O}$ resultado é um processo que avança de forma intermitente.

É possível constatar uma dinâmica similar condicionando o processo de integração regional sob a égide da UNASUL, liderado pelo Brasil, cujas ambiguidades estão referidas, em última análise, aos constrangimentos objetivos para conciliar "um elemento externo, o liberalismo, a outro interno, o desenvolvimentismo brasileiro" (Cervo, 2003), nos marcos de uma política econômica ortodoxa. Os óbices para modificar a política econômica brasileira incidem sobre a orientação do processo de integração regional em curso, limitando seu alcance e profundidade. Como decorrência, vislumbra-se uma política que tem como principal vetor econômico a internacionalização de negócios de capital brasileiro, e como principal limite político, os constrangimentos para conciliar um horizonte de integração pautado por um regionalismo desenvolvimentista, aos interesses locais vinculados ao capital internacional. Longe de ser uma peculiaridade brasileira, dificuldades de natureza similar atravessam a política dos demais países do subcontinente, resultando em pressões que corroboram para restringir a dimensão econômica da integração, relegando o processo, em grande medida, à sua dimensão política. 
Em suma, podemos identificar uma correspondência entre o avanço e os limites para a superação do neoliberalismo na América Latina a partir do início do século XXI e o sentido e o alcance da integração regional em curso. Por um lado, a onda de eleições de candidatos identificados com o campo progressista na esteira do desgaste resultante da aplicação da agenda neoliberal, expressou uma rejeição clara e generalizada às políticas prevalentes, que se refletiu na corrosão da legitimidade dos partidos convencionais em numerosos países. No plano da integração regional, este movimento incidiu no rechaço à ALCA, que abriu campo para novas estratégias associativas, seja nos marcos do livre-comércio, concretizada na assinatura de diversos tratados bilaterais com os Estados Unidos na região, seja em oposição a esta lógica, expressa de modo mais evidente na proposição da ALBA.

Desde logo, a incorporação do México ao NAFTA nos anos 1990 debilitou propostas envolvendo o conjunto do subcontinente em uma perspectiva autônoma, e embora a ALBA recebesse adesões na América Central e no Caribe, a política externa da principal economia da região adotou uma orientação expressamente sul-americana. Diante deste quadro, em que a persistência de políticas de orientação livre-cambista em Chile, Colômbia e Peru obsta o alcance do Mercosul, enquanto o desinteresse brasileiro limita o peso da ALBA, a constituição da UNASUL em 2008 afirmou-se como uma espécie de máximo denominador comum possível entre os países sul-americanos.

A criação da CELAC dois anos depois parece replicar este movimento em escala continental, em uma iniciativa que sinaliza para uma autonomização política em relação à OEA. Por outro lado, a formalização da Aliança do Pacífico em 2012 integrando Chile, Colômbia, Peru, México e mais recentemente, Costa Rica, estendeu o alcance da clivagem sul-americana. Portanto, se estas duas iniciativas mais recentes transcendem a divisão entre América do Sul, Central, Norte e Caribe, implícita inclusive na UNASUL, os termos em que se consolida a Aliança do Pacífico remetem às premissas da ALCA, acentuando as dificuldades para uma integração de sentido soberano.

Assim, observa-se que o sentido da integração regional na América Latina e Caribe é um processo em disputa, em que há clivagens de diferente natureza: regional, entre UNASUL, SICA, CARICOM e NAFTA, incorporando diferentes sub-regiões; de orientação político-econômica, entre Mercosul e Aliança do Pacífico, além do próprio NAFTA em oposição a ALBA; de cunho civilizatório, entre o Sumak Kawsay e o extrativismo, ou entre "pachamamismo" e "neodesenvolvimentismo".

Porém, vislumbrada em um horizonte histórico de longo prazo, no qual se projeta uma integração latino-americana e caribenha emancipadora, a constituição da UNASUL e da CELAC expressam passos importantes na direção de uma autonomia política da região, premissa necessária para uma segunda independência, assim como foi da primeira. No plano cultural, são iniciativas que recolocam na pauta política continental a problemática da integração, alijadas do debate violentamente entre os anos 1960 e 1970. Neste sentido, é sintomático o afloramento de temáticas como o "neodesenvolvimentismo", que remete à tradição cepalina, ou o debate em torno de um "subimperialismo" brasileiro, que remonta a Marini. Mais além das críticas e discordâncias que sua evocação presente possa suscitar, seu mero ressurgir sinaliza a retomada de uma tradição intelectual crítica, que correspondeu em sua época a um movimento da história que colocava a integração regional como uma necessidade histórica. Mais um sintoma de que na América Latina, longe do fim da história, vive-se no máximo um recomeço. 


\section{Conclusão}

Iniciamos este ensaio resgatando o contexto político e ideológico na origem da expressão "América Latina", com o propósito de deduzir as premissas que fundamentam a atualidade desta noção no século XXI. Indicamos que a pertinência do conceito está relacionada à integração regional como estratégia de inserção internacional, balizada pelo desígnio de assumir o controle sobre o tempo e o ritmo da mudança social no continente no contexto do imperialismo.

Portanto, quando Leslie Bethell afirma que o conceito de América Latina "seguramente perdeu a utilidade que talvez tenha tido alguma vez", inferimos que o historiador inglês considera desatualizada ou irrelevante a problemática que motivou sua origem, qual seja, a natureza assimétrica e predatória da relação entre os Estados Unidos e os demais países da região ${ }^{18}$. Esta é uma leitura política possível, embora contestada por uma ampla e plural tradição crítica latino-americana, que situa a questão do imperialismo - ou para usar os termos da CEPAL, das relações centro-periferia - no âmago da problemática do subdesenvolvimento.

Por outro lado, ao considerar que o sentido do termo América Latina se esvaziou desde que o México aderiu ao NAFTA e o Brasil orientou sua política externa na direção da América do Sul sob a égide da UNASUL, Bethell assume como dados processos políticos em curso e portanto, objetos de disputa. Recordemos o levantamento zapatista em Chiapas em $1^{\circ}$ de janeiro de 1994 , mesmo dia em que entrou em vigor o NAFTA, ou o plebiscito popular sobre a ALCA em 2002, ponto culminante de uma intensa mobilização social contra esta proposta no Brasil, e que incidiu no fracasso da iniciativa. Para aqueles que consideram irreversível os rumos da política mexicana, é pertinente lembrar que, embora os processos históricos não sejam reversíveis - porque o próprio tempo não o é -, tampouco são inexoráveis. Para dar dois exemplos aleatórios, eram raros os franceses que no começo do século XX, imaginavam uma Argélia independente, ou os soviéticos que vislumbraram o esfacelamento da União quando morreu Stálin. Nesta perspectiva, a naturalização de um contexto político em disputa revela-se como um procedimento intelectual antidemocrático, na medida em que ignora o potencial de mudança social inerente à própria história, o que na era neoliberal ressoa à ideologia do fim da história.

Nesta perspectiva, reivindicar a atualidade do conceito de América Latina significa posicionar-se criticamente em relação às políticas que reafirmam uma inserção internacional da região subordinada aos Estados Unidos e que como decorrência, reforçam a fragmentação continental, como é o caso do Plan Colombia, do NAFTA, dos Tratados de Livre Comércio assinados por diversos países em anos recentes, da Aliança do Pacífico, entre outras. De modo correspondente, sugerir que a noção de América Latina está ultrapassada justamente em função de políticas desta natureza, revela um empenho em transformar uma questão em disputa em um fato consumado, operação característica da ideologia e não do pensamento crítico.

Em outras palavras, se a noção de América Latina terá vitalidade conceitual em anos futuros é uma questão em aberto, a ser resolvida não na academia mas sim no terreno da política, no qual os intelectuais tem um papel relevante, mas limitado. Afinal, há sempre o risco de que a teoria seja atropelada pela história. Pois como disse um

\footnotetext{
${ }_{18}$ Esta leitura é coerente com a linha interpretativa de seus trabalhos, exemplificada em artigo sobre a Guerra do Paraguai em que desconsidera o papel dos ingleses como financiadores dos aliados, evidenciado no livro de Pomer, citado pelo próprio Bethell. Bethell, 1995; Pomer, 1968. Sua perspectiva ideológica incidiu no critério de seleção dos colaboradores da História da América Latina que organizou para a Cambridge. Por exemplo, Fernando Novais conta que teve sua contribuição elaborada em parceria com Carlos Guilherme Mota rejeitada, e substituída por um artigo do próprio Bethell. Este texto foi posteriormente publicado como "A independência política do Brasil" (Mota \& Novais, 1996).
} 
militante do Movimento dos Trabalhadores Rurais Sem-Terra (MST), se esqueceram de avisar o nosso pessoal que acabou a luta de classes. Neste sentido, a constituição da CELAC no México foi mais eloquente do que qualquer réplica que a academica pudesse produzir, lembrando que a política, como dimensão da história, é um processo dinâmico e infinito.

Nesta perspectiva, a constatação de que a maioria dos brasileiros não se identifica com a América Latina, a respeito da qual sabem muito pouco, não deve ser interpretada como evidência natural da desconexão do país com sua região geográfica, mas antes como um indício de força do que Candido descreveu como o "movimento conservador" no Brasil. A mesma leitura se aplica às visões preconceituosas sobre os latino-americanos, que prevalecem no senso comum. Devemos lembrar que as identidades nacionais e regionais são construções históricas, que se afirmam por oposição e se modificam no tempo ${ }^{19}$.

Em sua trilogia sobre o orientalismo, Edward Said atenta para uma dimensão do discurso orientalista que caracteriza a sociedade contemporânea, em que os meios de comunicação de massas expressam a hegemonia estadunidense, ou ocidental: os estereótipos que informam a produção e circulação de notícias sobre o mundo não europeu balizam a formação de opinião entre os próprios povos deformados por esta "cobertura", cujo caráter ideológico resulta em um "acobertamento" 20 . De modo análogo, entendo que o "descobrimento" da América Latina pelos brasileiros e demais latino-americanos é e será uma construção política, justificada pelo desígnio de solidificar laços entre povos interessados em superar dilemas históricos comuns.

Nesta perspectiva, a despeito das limitações que enfrentam para avançar, referidas aos óbices que os governos progressistas encontram na América Latina e no mundo para superar efetivamente o neoliberalismo, os processos integracionistas em curso contribuem para recolocar na agenda política e no debate público a integração continental como uma necessidade histórica. Esta tarefa deve ser enfrentada com criatividade, reconhecendo a especificidade da formação histórica continental; com determinação política, encarando o desafio de subordinar o movimento da economia à sociedade; com generosidade para superar ressentimentos, mas também assimetrias; com radicalidade, assimilando as lições históricas legadas por experiências anteriores e pelo pensamento crítico a elas referido; com persistência, para afirmar um ideário que associe nação e integração continental à superação da dependência e da desigualdade; com originalidade, na medida em que as condições objetivas e subjetivas para uma integração emancipadora apontam para um horizonte civilizatório próprio.

Longe de ser um fim em si, a integração latino-americana é entendida no campo democrático como um meio para proteger os interesses da comunidade continental dos efeitos destrutivos da concorrência intracapitalista em geral, e da sanha estadunidense em particular. Nesta perspectiva, a identidade latino-americana pretende dissolver-se, em um futuro em que a oposição aos Estados Unidos que a define, se esvaziar. É o compromisso com este horizonte civilizatório alternativo acenado por José Martí, em que as identidades serão afirmadas não mais de modo adversativo, mas aditivo, que fundamenta a atualidade política do projeto de unidade continental.

\footnotetext{
${ }^{19}$ Há um disco de Vinícius de Morais gravado ao vivo em Buenos Aires em 1970 em que o poeta inicia sua apresentação agradecendo, de modo sincero, o apoio dos argentinos a equipe brasileira tri-campeã mundial. Não conheço pesquisas sobre o tema, mas intuo que a rivalidade entre Argentina e Brasil é uma construção das ditaduras militares, reforçada atualmente de modo exaustivo pela publicidade comercial.

${ }^{20}$ Daí o jogo de palavras no título de um dos livros de Said: "Covering Islam", referindo-se ao "acobertamento" ideológico operado pelas "coberturas" jornalísticas sobre o tema no Ocidente (Said, 1981).
} 


\section{Referências Bibliográficas}

Abelardo Ramos, Jorge 2012 (1968). História da Nação Latino-Americana. 2a ed. revisada. (Florianópolis: Insular).

Acosta, Alberto 2009. La Maldición de la abundancia. (Quito: Ed. Abya Yala).

Anderson, Benedict 2003 (1982). Imagined Communities. (Londres: Verso).

Ángel Barrios, Miguel 2007. El latinoamericanismo en el pensamiento de Manuel Ugarte. (Buenos Aires: Biblos).

Arceo, Enrique; Basualdo, Eduardo (comp.) 2006. Neoliberalismo y sectores dominantes. Tendencias globales y experiencias nacionales. (Buenos Aires: CLACSO)

Ardao, Arturo 1965. "La idea de Latinoamerica". (Montevideo: Semanario Marcha), 1282, 27 de noviembre de 1965;

Ardao, Arturo 1980. Genesis de la idea y el nombre de América Latina. (Caracas: Centro de Estudios Latinoamericanos "Romulo Gallegos").

Aricó, José 1999. La hipótesis de Justo. (Buenos Aires: Sudamericana).

Arosemena, Justo 1982. Fundación de la nacionalidad panameña. Caracas: Fundación Biblioteca Ayacucho, 1982.

Arroyo Picard, Alberto. 'México a 14 años del TLCAN: realidad y propaganda', em: Sandoval Palacios, Juan Manuel 2009. TLCAN: Balance general e impactos subregionales y sectoriales. (México: Red Mexicana de Acción frente al Libre Comercio). Disponível em: 7/9/2013.

$\langle$ http://www.rmalc.org.mx/documentos/libros/tlcan2009.pdf $\rangle$. Acesso em

Assadourian; Cardoso; Ciafardini et al 1973. Modos de producción en América Latina. (Bogotá: Cuadernos del Pasado y Presente), n. 40.

Baggio, Katia Gerab 1998. A "outra" América: a América Latina na visão dos intelectuais brasileiros das primeiras décadas republicanas. (São Paulo) Tese de Doutorado, FFLCH-USP.

Bartesaghi, Lúcia; Ceroni, Mauricio; Díaz, Ismael 2006. Infraestructura Regional Sudamericana. Otro paso en la explotación de los pueblos y territorios sudamericanos. (Montevideo: Programa Uruguay Sustentable Redes - Amigos de la Tierra).

BASE IS 2010. Los impactos socioambientales de la soya en Paraguay. (Asunción: Base IS).

Bethell, Leslie (Org.). História da América Latina. São Paulo: EDUSP; Brasília: Fundação Alexandre Gusmão, 1997-2009.

Bethell, Leslie (Org.). The Cambridge history of Latin America. Cambridge: Cambridge University Press, 1990-1996. 
Bethell, Leslie 2009. "O Brasil e a ideia de "América Latina" em perspectiva histórica" (Rio de Janeiro) Estudos Históricos, v. 22, no 44.

Bethell, Leslie. 'O imperialismo britânico e a Guerra do Paraguai' em Marques, Maria Eduarda Castro Magalhães 1995. A Guerra do Paraguai - 130 anos depois. (Rio de Janeiro: Relume- Dumará). Pomer, Leon 1968. La guerra del Paraguay: gran negocio! (Buenos Aires).

Bethell, Leslie. "O Brasil e a ideia de "América Latina" em perspectiva histórica" em Estudos Históricos, (Rio de Janeiro) v. 22, nº 44, jul/dez, 2009.

Blackburn, Robin (org.) 2005. Depois da queda. O fracasso do comunismo e o futuro do socialismo. 3. ed. (São Paulo: Paz e Terra).

Bohórquez Morán, Carmen L. 2003. Francisco de Miranda. Precursor de las independencias de la América Latina. (La Habana: Editorial de Ciencias Sociales).

Borón, Atílio 2008. America Latina en la geopolítica del imperialismo. (Buenos Aires: Luxemburg). Martins, Carlos Eduardo 2011. Globalização, dependência e neoliberalismo na América Latina. (São Paulo: Boitempo).

Botafogo, José Gonçalves 2013. "Prioridades da política externa brasileira à luz do interesse nacional" em Paz, Leonardo (org.). O CEBRI e as Relações Internacionais no Brasil. (São Paulo: SENAC).

Brenner, Robert 2003. O boom e a bolha. Os Estados Unidos na economia mundial. (Rio de Janeiro: Record).

Candido, Antonio 1990. "Radicalismos". (São Paulo) Revista do Instituto de Estudos Avançados, USP, v. 4, n. 8, jan./apr. 1990. Disponível em: <http://www.scielo.br/scielo.php?script=sci_arttext\&pid=S0103-

40141990000100002>. Acesso em: 9 de março de 2011.

Cardoso, Fernando Henrique 1975. O modelo político brasileiro e outros ensaios. 4a ed. (Rio de Janeiro: Difel).

Cardoso, Fernando Henrique; Faletto, Enzo 1977 (1969). Dependência e desenvolvimento na América Latina. (Rio de Janeiro: Zahar).

Cervo, Amado Luiz 2003. "Política exterior e relações internacionais do Brasil: enfoque paradigmático". (Brasília) Rev. bras. polít. int., v. 46, n. 2.

Clinton, Hillary Rodham, Secretary of State 2010. "Address to the Organization of American States General Assembly". (Lima) 7 de junho de 2010. Disponível em: http://www.state.gov/secretary/rm/2010/06/142804.htm. Acesso em 20 de julho de 2011.

Cotler, Julio. "Perú: Estado oligarquico y reformismo militar" em González Casanova, Pablo 1984. América Latina: História de medio siglo. (México, Siglo XXI).

Dávalos, Pablo 2008. Reflexiones sobre el sumak kawsay (el buen vivir) y las teorías del desarrollo. (Quito: Alai) Disponível em: http://alainet.org/active/25617\&lang=es Acesso em 26 de agosto de 2010.

Desidera Neto, Walter; Teixeira, Rodrigo 2012. "La recuperación del Desarrollismo en el Regionalismo Latinoamericano" em . Perspectivas para la integración de América Latina. (Brasília: CAF; IPEA).

Devés Valdés, Eduardo 2000. Del Ariel de Rodó a la Cepal (1900-1950). (Buenos Aires: Biblos).

Dos Santos, Theotonio. Imperialismo y dependencia 2011 (1978). (Caracas: Fundación Biblioteca Ayacucho).

Fals Borda, Orlando 1968. Las revoluciones inconclusas en América Latina: 18091968. (México, Siglo XXI). 
Fernandes, Florestan 1975 (1972). Capitalismo Dependente e classes sociais na América Latina. (Rio de Janeiro: Zahar).

Fernández Retamar, Roberto 2005. Pensamiento de Nuestra América. (Buenos Aires: Clacso)

Fernandez Retamar, Roberto. Todo Caliban. (Buenos Aires: CLACSO, 2004).

Fernández, Teodosio 2000. 'España y la cultura hispanoamericana tras el 98' em: Royano, Lourdes (ed.). Fuera del olvido: los escritores hispanoamericanos frente a 1898. (Santander: Servicio de Publicaciones de la Universidad de Cantabria).

Firmin, Joseph Antenor 2005. De l'égalité des races humaines: anthropologie positive. (Montreal: Mémoire d'encrier).

Fontes, Virgínia 2012. O Brasil e o capital-imperialismo. Teoria e história. 3ed., (Rio de Janeiro: UERJ).

Furtado, Celso 1966. Subdesenvolvimento e estagnação na América Latina. (Rio de Janeiro: Civilização Brasileira).

Furtado, Celso 1974. O mito do desenvolvimento econômico. (Rio de Janeiro: Paz e Terra).

Furtado, Celso 1986. A economia latino-americana. (São Paulo: Companhia Editora Nacional).

Galasso, Norberto 2001. Manuel Ugarte y la lucha por la unidad latinoamericana. (Buenos Aires: Corregidor).

Gleijeses, Piero 2004. La esperanza destrozada. La revolución guatemalteca y los Estados Unidos (1944-1954). (La Habana: Editorial de Ciencias Sociales).

González Casanova, Pablo. Apud: Fernández Retamar, Roberto 2006. Pensamiento de nuestra América. Autoreflexiones y propuestas. (Buenos Aires: CLACSO).

Gordon, Todd; Webber, Jeffery. "The Overthrow of a Moderate and the Birth of a Radicalizing Resistance: The Coup against Manuel Zelaya and the History of Imperialism and Popular Struggle in Honduras", em: Carr, Barry; Webber, Jeffery 2013. The new Latin American Left: Cracks in the Empire. (Lanham: Rowman \& Littlefield Publishers Inc.), ps. 357-381.

Gowan, Peter 2003. A roleta global. Rio de Janeiro: Record.

Gudynas, Eduardo 2010. "Si eres tan progresista porque destruyes la naturaleza? Neoextractivismo, izquierda y alternativas". (Quito) Ecuador Debate, ps. 61-81

Hadler, João Paulo de Toledo Camargo 2013. Dependência e super-exploração: os limites das reflexões de Fernando Henrique Cardoso e Ruy Mauro Marini sobre o capitalismo dependente. (Campinas) Tese de Doutorado, Instituto de Economia da UNICAMP.

IIRSA 2011. IIRSA 10 anos depois: Suas conquistas e desafíos. (Buenos Aires: BID INTAL).

ILPES (Instituto Latinoamericano de Planificación Económica y Social) 1967. "La estrategia de industrialización en América Latina" (1967), em Nolff, Max C. (org.) 1975. Desarollo industrial latinoamericano. (México: FCE).

Katz, Friederich 1998. The life and times of Pancho Villa. (Stanford: Stanford

University Press).

Kay, Cristóbal 1989. Latin american theories of development and underdevelopment. (London: Routledge).

Klein, Naomi 2008. A doutrina do choque: a ascensão do capitalismo de desastre. (São Paulo: Nova Fronteira).

La juventud argentina de Córdoba a los hombres libres de sudamerica, em: Portantiero, Juan Carlos 1978. Estudiantes y política en América Latina. 1918-1930. El proceso de la reforma universitaria. (México: Siglo XXI).

LaFEBER, Walter 1969. The New Empire. An Interpretation of American Expansion. (New York: Cornell University Press). 
Löwy Michael (Org.) 2003. O marxismo na América Latina - uma antologia de 1909 aos dias atuais. (São Paulo: Perseu Abramo).

Luce, M. S. 2007. O subimperialismo brasileiro revisitado: a política de integração regional do governo Lula (2003-2007). (Porto Alegre) Dissertação de Mestrado em Relações Internacionais, Universidade Federal do Rio Grande do Sul.

Mariátegui, José Carlos, 1990. Temas de Nuestra América. $11^{\text {a }}$ edição (Lima: Amauta).

Marini, Ruy Mauro 2000. Dialética da Dependência. Uma antologia da obra de Ruy Mauro Marini. (Petrópolis: Vozes; Buenos Aires: CLACSO)

Marini, Ruy Mauro 2013 (1969). Subdesenvolvimento e Revolução. Florianópolis: Insular, 2013.

Martí, José 2000. Obras Escogidas. 3 tomos. (La Habana: Editorial de Ciencias Sociales).

McGuiness, Aims 2008. Path of Empire. Panama and the California Gold Rush. (Ithaca: Cornell University Press).

Mello e Souza, André; Oliveira, Tiago Machado; Gonçalves, Samo Sérgio 2010. "Integrando desiguais: assimetrias estruturais e políticas de integração no Mercosul" em: Acioly, Luciana; CINTRA, Marcos Antonio Macedo. Inserção internacional brasileira: temas de política externa. Vol. 1. (Brasília: IPEA), ps. 277-326.

Mendez, Idilio 2012. "Monsanto golpea en Paraguay: Los muertos de Curuguaty y el juicio político a Lugo". Disponível em: http://www.atilioboron.com.ar/2012/06/porque-derrocaron-lugo.html. Acesso em 5 de agosto de 2012.

Mészaros, Istvan 1996. Beyond Capital. (New York: Monthly Review Press).

Mignollo, Walter 2005. The Idea of Latin America. (Oxford: Blackwell).

Moniz Bandeira, Luis Alberto 1998. Relações Brasil-EUA no contexto da globalização. I - Presença dos EUA no Brasil. (São Paulo: SENAC).

Mota, Carlos Guilherme; Novais, Fernando 1996. A independência política do Brasil. $2^{\mathrm{a}}$ edição (São Paulo: Hucitec).

Nickson, Andrew 2012. "Paraguay's presidential coup: the inside story". Open Democracy, 10/7/2012. Disponível em: http://www.opendemocracy.net/andrewnickson/paraguays-presidential-coup-inside-story. Acesso em 9 de setermbro de 2012. Nolff, Max C. (org.) 1975. Desarollo industrial latinoamericano. (México: FCE).

Novoa Garzón, Luis Fernando 2011. "Brasil, via BNDES reforça caráter regressivo da integração latino-americana". (São Paulo) Entrevista ao Correio da Cidadania, 19/11/2011.

Panitch, Leo; Gindin, Sam 2006 (2004). "Capitalismo global e império norteamericano' em Socialist register 2004: O novo desafio imperial. (Buenos Aires: Consejo Latinoamericano de Ciencias Sociales).

Phelan, John L 1986 (1965). "El origen de la idea de Latinoamérica" em Ideas en torno de Latinoamérica. México: UNAM/ Unión de Universidades de América Latina, 1986.

Pinedo, Javier 2010. "El concepto Segunda Independencia en la historia de las ideas en América Latina: Una Mirada desde el Bicentenario" em Revista Atenea (Concepción) $\mathrm{N}^{\circ}$ 502, ps. 151-177.

Plan del Partido Liberal em Díaz, Lilia 1974. Planes políticos y otros documentos. Fuentes para la historia de la Revolución Mexicana. Prólogo de Manuel González Ramirez. $1^{\mathrm{a}}$ reimpresión. (México: FCE).

Polanyi, Karl 2001 (1944). The great transformation: the political and economic origins of our time. Boston: Beacon press. 
Portantiero, Juan Carlos 1978. Estudiantes y política en América Latina. 1918-1930. El proceso de la reforma universitaria. (México: Siglo XXI).

Prado, Eduardo 2001 (1893). A ilusão americana. (São Paulo: Alfa-Ômega).

Prebisch, Raúl 2000 (1949). "O desenvolvimento econômico da América Latina e alguns de seus principais problemas" em: Bielchowsky, Ricardo (Org.) 2000. Cinqüenta anos de pensamento na CEPAL. (Rio de Janeiro: Record).

Programa da Unidade Popular (1970) em Carlos, Newton; Freitas, Galeno de; Vettori, Marcia 1970. Chile com Allende, para onde vai? (Rio de Janeiro: Gernasa).

Quijada, Monica 1998. "Sobre el orígen y difusión del nombre 'América Latina'(o una variación heterodoxa en torno al tema de la construcción social de la verdad)" em Revista de Indias, 1998, vol. LVIII, n. 214, pp. 595-616.

Rodríguez, Octávio 1981. Teoria do subdesenvolvimento da CEPAL. (Rio de Janeiro: Forense-Universitária).

Rojas Mix, Miguel 1986. "Bilbao y el hallazgo de América latina: Unión continental socialista y libertaria" em Cahiers du Monde Hispanique et Luso-Brasilien-Caravelle, (Toulouse) n. 46, 1986, ps. 35-47.

Rostow, W. W 1974 (1960). Etapas do desenvolvimento econômico. 5a ed. (Rio de Janeiro: Zahar).

Said, Edward 1981. Covering Islam. New York: Pantheon Books.

Sanajuja, José Antonio 2012. "Regionalismo post-liberal y multilateralismo en Sudamérica: El caso de UNASUR" em Serbin, Andrés; Martínez, Laneydi; Ramazini Júnior, Haroldo 2012; El regionalismo "post-liberal" en América Latina y el Caribe: Nuevos actores, nuevos temas, nuevos desafíos. Anuario de la Integración Regional de América Latina y el Gran Caribe 2012. (Buenos Aires: Coordinadora Regional de Investigaciones Económicas y Sociales).

Stavenhagen, Rodolfo (1965). "Siete tesis equivocadas sobre América Latina" em Illades, Carlos y Suárez, Rodolfo (coordinadores) 2012. México como problema. Esbozo de una historia intelectual. (México, Siglo XXI Editores. Universidad Autónoma Metropolitana (Unidades Iztapalapa y Cuajimalpa).

Tavares, Maria da Conceição; Serra, José 1970. "Além da estagnação" em: Tavares, Maria da Conceição 1975. Da substituição de importações ao capitalismo financeiro. 4a ed. (Rio de Janeiro: Zahar).

Teixeira, Carlos Gustavo Poggio 2011. "Brazil and the institutionalization of South America: from hemispheric estrangement to cooperative hegemony." Rev. Bras. Polit. Int. 54 (2): 189-211.

Thostensen, Vera 2014. "Entrevista a Carta Capital". (São Paulo) 19 de maio de 2014. Disponivel em: http://www.cartacapital.com.br/economia/ficar-atrelado-aomercosul-e-afundar-o-brasil-804.html. Acesso em 2 de junho de 2015.

Ugarte, Manuel 1987. La nación latinoamericana. (Caracas: Biblioteca Ayacucho).

Vigevanni, Tullo et al 2008. "O papel da integração regional para o Brasil: universalismo, soberania e percepção das elites".(Brasília) Rev. bras. polít. int., v. 51, n. 1.

Webber, Jeffery; Carr, Barry 2013. The new Latin American left. Cracks in the Empire. (Lanham: Rowman \& Littlefield Publishers, Inc.).

Williams, William Appleman 1962. The tragedy of American diplomacy. Revised and enlarged edition. (Nova Iorque: Delta Book).

Wood, Ellen Meiksins, 2011. Democracia contra capitalismo. (São Paulo: Boitempo). Zea Leopoldo. El pensamiento latinoamericano. (Barcelona: Ariel, 1976).

(Org.). Fuentes de la Cultura Americana. México: Fondo de Cultura 
Económica, 1993. . América Latina en sus ideas. Paris: Unesco; México: Siglo Veintiuno, 1986.

Zea, Leolpoldo (compilador) 1995. Fuentes de la cultura latinoamericana. (México: FCE). Rodríguez, Simón 1990. Sociedades Americanas. (Caracas: Biblioteca Ayacucho).

Zea, Leopoldo 1976. El pensamiento latinoamericano. (Barcelona: Ariel).

Zibechi, Raul 2012. Brasil Potencia: entre la integración regional y un nuevo imperialismo. (Bogotá: Ediciones desde Abajo). 